\title{
Predictive mapping of reproductive fish habitats to aid marine conservation planning
}

\begin{tabular}{|r|l|}
\hline Journal: & Canadian Journal of Fisheries and Aquatic Sciences \\
\hline Manuscript ID & cjfas-2015-0538.R3 \\
\hline Danuscript Type: & Article \\
\hline Complete List of Authors: & $\begin{array}{l}\text { Schmiing, Mara; Institute of Marine Research, University of the Azores, } \\
\text { Department of Oceanography and Fisheries; MARE - Marine and } \\
\text { Environmental Sciences Centre, University of the Azores, Department of } \\
\text { Oceanography and Fisheries } \\
\text { Fontes, Jorge; MARE - Marine and Environmental Sciences Centre, } \\
\text { University of the Azores, Department of Oceanography and Fisheries; IMAR } \\
\text { - Institute of Marine Research, University of the Azores, Department of } \\
\text { Oceanography and Fisheries } \\
\text { Afonso, Pedro; MARE - Marine and Environmental Sciences Centre, } \\
\text { University of the Azores, Department of Oceanography and Fisheries; IMAR } \\
\text { - Institute of Marine Research, University of the Azores, Department of } \\
\text { Oceanography and Fisheries }\end{array}$ \\
\hline Keyword: & $\begin{array}{l}\text { FECUNDITY < General, spawning biomass, larval subsidy, MARINE } \\
\text { PROTECTED AREAS < Environment/Habitat, GAMLSS }\end{array}$ \\
\hline
\end{tabular}


1 Title: Predictive mapping of reproductive fish habitats to aid marine conservation planning

2

3

4 Authors: Mara Schmiing*1,2, Jorge Fontes ${ }^{1,2}$, Pedro Afonso ${ }^{1,2}$

7 Address: ${ }^{1}$ MARE - Marine and Environmental Sciences Centre, University of the Azores,

8 Rua Professor Doutor Frederico Machado 4, 9901-862 Horta, Azores, Portugal

$9{ }^{2}$ IMAR - Institute of Marine Research, University of the Azores, Rua Professor Doutor

10 Frederico Machado 4, 9901-862 Horta, Azores, Portugal

* Corresponding author: Mara Schmiing, MARE, IMAR, University of the Azores, Rua

14 Prof. Doutor Frederico Machado 4, 9901-862 Horta, Portugal. Tel.: (+351) 292200 400, Fax:

15 (+351) 292200 411. E-Mail: mara.schmiing@gmail.com

19 Running title: Reproductive habitats

Keywords: fecundity, spawning biomass, larval subsidy, marine protected area, GAMLSS 


\section{Abstract}

25 Post-settlement spillover from marine protected areas (MPAs) can support adjacent fished 26 populations and has been subject of many scientific studies. The larval subsidy effect, on the 27 contrary, is more challenging to study and less demonstrated although it, arguably, provides

28 key benefits for fisheries. We modeled and predicted the spatial distribution of fish spawning 29 biomass and fecundity across a temperate insular MPA network (Azores archipelago, 30 Northeast Atlantic) and identified potential single and multi-species reproductive habitats 31 (RHs) in shallow reefs. Reproductive strategies or skewed sex ratios influenced spatial 32 patterns of potential spawning biomass and fecundity. Predicted multi-species RHs covered $33 \quad 5-20 \%$ of the studied reef habitat. Given their potentially high reproductive output we argue 34 that such sites should be considered in marine conservation planning to increase chances of 35 achieving fisheries and conservation benefits. Spatial patterns of the reproductive output may 36 function as surrogates for larval subsidy when limited or no larval connectivity information is 37 available and assist in identifying potential larval sources and priority sites for conservation. 


\section{Introduction}

39 Well planned marine protected areas (MPAs) and especially marine reserves (MRs) can replenish fish populations by enhancing fish abundance, size, and biodiversity within their boundaries (Halpern 2003; McCook et al. 2010; Kelaher et al. 2014). Fisheries then may benefit from a subsequent spillover of juvenile or adult fish (spillover effect), and from larval dispersal (larval subsidy effect) to adjacent, fished areas (Goñi et al. 2008; Planes et al. 2009; Pelc et al. 2010). The dispersal of early life history stages of fishes, pelagic eggs and larvae, is affected by a variety of biotic, abiotic and physical factors, such as pelagic larval duration (PLD), food availability, predation, swimming abilities, and transport by ocean currents (e.g., Pineda et al. 2007; Di Franco et al. 2012; Andrello et al. 2015; Koeck et al. 2015). Larvae can be retained locally, close to the natal population, or are dispersed to more distant locations, up to several hundred kilometers (Berumen et al. 2012; Di Franco et al. 2012; Treml et al. 2012; Thomas et al. 2014). Various factors then affect the recruitment success, such as larval behavior, habitat choice (and availability) at settlement, and post-settlement survival (Pineda et al. 2007; White and Caselle 2008; Felix-Hackradt et al. 2013; Soeparno et al. 2013). Larval subsidy and settler abundance, however, will depend on the reproductive potential of the adult fish population in the first place. This, in turn, is determined by the magnitude of the reproductive output or the spawning biomass, with older, large-sized specimens generally producing more and better eggs (Berkeley et al. 2004). Protecting mature adults may enhance the reproductive output and the potential larval subsidy to adjacent habitats (Birkeland and

58 Dayton 2005; Pelc et al. 2010; Treml et al. 2012). The extent of realized larval dispersal and the degree of connectivity in fish populations will largely determine if a MPA network can

60 effectively promote fishery yields and sustainability (Sale et al. 2005; Botsford et al. 2009;

61 D'Aloia et al. 2015). 
62 Most empirical studies focus on adult or juvenile spillover and migration across MPA 63 boundaries (e.g., Goñi et al. 2008, Harmelin-Vivien et al. 2008, Afonso et al. 2009), whereas 64 measuring larval connectivity and integrating it into MPA design remains challenging (Sale 65 et al. 2005; Lagabrielle et al. 2014; D'Aloia et al. 2015). Nevertheless, different methods exist 66 to estimate connectivity, and progress in recent years has shown local and large-scale larval 67 seeding between MPAs and unprotected sites (e.g., Planes et al. 2009; Christie et al. 2010; Di 68 Franco et al. 2012; Harrison et al. 2012). The use of 'connectivity surrogates' has been 69 proposed as alternative for incorporating connectivity in conservation planning when other 70 information or direct measurements on larval dispersal patterns are absent (Bode et al. 2012). 71 Surrogates reflect easy measurable characteristics of reef communities, such as the spawning 72 biomass of fishes that outperformed surrogates based on physical dimensions of reefs (Bode 73 et al. 2012). Considering habitats with a great amount of a given surrogate in MPA site 74 selection processes may support connectivity, although using surrogates will never be as 75 accurate as incorporating measured connectivity patterns.

76 An effective spatial management requires solid information about the spatial distribution of 77 species, habitats and other ecological/biological/socio-economic features (Klein et al. 2008; 78 Green et al. 2009; Costello et al. 2010). Often such information only exists for a few sampled 79 locations and statistical modelling techniques are applied to predict the distribution also in 80 non-surveyed areas. Resulting predictive maps can then be used to evaluate existing MPA 81 networks and assist site selection (Sundblad et al. 2011; Schmiing et al. 2015), if modelling 82 techniques are thoroughly implemented and in concordance with statistical assumptions 83 (Schmiing et al. 2014b).

84 MPAs have been established worldwide, for example to preserve biodiversity, prevent 85 ecosystem degradation, and as additional fisheries management tool (Russ 2002; Botsford et 86 al. 2009; McCook et al. 2010). First MPAs were established in the 1980's to manage marine 
87 resources in the Azores, the most isolated archipelago of nine islands in the Northeast 88 Atlantic (Santos et al. 1995; Abecasis et al. 2015b). Since then, several advances in marine 89 conservation took place, including EU-driven initiatives, and today exists 1) a network of 90 nine Island Natural Parks (INPs) that include all terrestrial and coastal MPAs within the 91 territorial sea (12 NM), and 2) the Azorean Marine Park, including all MPAs outside 92 territorial waters (Calado et al. 2009, 2011; Abecasis et al. 2015b). Although these MPAs 93 have strengths (e.g. establishment considered pioneer, involvement of scientific community, 94 and legal requirement for stakeholder consultation), their design is largely inadequate, very 95 few no-take areas exist, management plans are missing, low recourses for enforcement are 96 available, and community involvement and public outreach is weak (Calado et al. 2011; 97 Abecasis et al. 2015b).

98 In the present study we quantify spatial patterns of the reproductive potential of eight 99 common reef fish species through predictive modeling of spawning biomass and potential 100 fecundity, using the Azores archipelago as case study. We focus on species with no known 101 movements between habitats during the reproductive season. In particular, we (1) produce 102 predictive maps of both reproductive metrics, (2) compare single- and multi-species spatial 103 patterns, (3) identify sites with potentially high reproductive output, (4) analyze the 104 significance of these potential reproductive habitats (RHs) for the existing MPA network, and 105 (5) discuss the use of both metrics as 'conservation surrogates' in marine spatial management 106 if data on connectivity patterns are absent. Results are expected to deliver new strategies in 107 support of marine conservation planning.

108

109 Material and Methods

110 Study site and fish counts 
111 The study area comprises shallow coastal habitats down to the $40 \mathrm{~m}$ isobath around Faial and

112 West Pico Islands, Azores, Northeast Atlantic (Fig. 1). Despite the limited geographic extent

113 the study area encompasses a wide range of environmental conditions, such as sheltered bays,

114 exposed coasts, offshore reefs, sandy bottoms, and a large variety of rocky substratum,

115 including bedrock reefs, boulder fields, cliffs, and submerged volcanic cones, that covers

116 more than half of the area $\left(59 \%, 34 \mathrm{~km}^{2}\right)$ (Tempera et al. 2012). Detailed descriptions, habitat

117 maps, environmental, and ecological information are available from previous studies (Santos

118 et al. 1995; Tempera 2008; Tempera et al. 2012; Schmiing et al. 2013, 2014b).

119 Faial and Pico have designated Island Natural Parks (INPs), comprising terrestrial and marine

120 protected areas (Calado et al. 2009) of which six coastal MPAs lie (partly) in the study area.

121 These MPAs cover about $60 \%$ of the study area and encompass most of the rocky substrate

$122\left(22 \mathrm{~km}^{2}\right.$ out of $\left.34 \mathrm{~km}^{2}\right)$. Regulations regarding extractive activities are not uniform and vary

123 from no limitations to prohibition of a certain fishing activity. Only a single, small no-take

124 reserve exists $(8 \mathrm{ha})$ at the south-east tip of Faial. However, MPA compliance and

125 enforcement are poor (Abecasis et al. 2015b, Diogo et al. 2015), and positive MPA effects

126 are widely missing (Schmiing et al. 2014a; Afonso et al., unpubl. data), thus no

127 differentiation is made between the protection levels of the MPAs for the purpose of the 128 present study.

129 Reef fish assemblages were surveyed between 1997 and 2004 with a total of 462 underwater 130 visual fish censuses (UVCs) along $50 \times 5 \mathrm{~m}$ SCUBA dive transects, using a random stratified 131 sampling design. Transects were parallel to the coast to stay within the same depth and 132 habitat strata (i.e. 10m depth increments, and rock or sediment) (see Schmiing et al. 2013 for 133 a detailed description). Fish were identified, counted, grouped into species-specific size 134 classes (small, medium, large, very large; Morato et al. 2001), and the sex was determined 135 whenever possible. A mean length in $\mathrm{cm}$ was assigned to the individual size classes of each 
136 species, using data from local populations (Morato et al. 2001). For the purpose of the present 137 study, all individuals of the size classes medium to very large were defined as mature. In a 138 next step, spawning biomasses (Ws, i.e. total biomass of mature individuals) of Abudefduf 139 luridus, Coris julis, Diplodus sargus, Labrus bergylta, Sarpa salpa, Serranus atricauda, 140 Sparisoma cretense and Symphodus caeruleus were estimated via species-specific length141 weight relationships (Morato et al. 2001). Furthermore, the total potential fecundity (i.e. 142 number of oocytes; Fp) of mature females of D. sargus, L. bergylta, S. atricauda, S. cretense 143 were calculated per transect, using published fecundity equations (Table 1). For this purpose, 144 the number of females of species with unidentified sex was estimated via sex ratios from 145 local populations, whenever possible per size class (Morato el al. 2003; unpubl. data). Study 146 species were chosen based on their ecological and/or commercial importance for rocky reefs 147 in the Azores (Schmiing et al. 2013) and their contrasting reproductive strategies. D. sargus 148 is a digynic hermaphrodite (Morato et al. 2003), S. atricauda is a simultaneous hermaphrodite 149 (García-Díaz et al. 2002), S. cretense is essentially gonochoristic with a prematurational sex150 change (de Girolamo et al. 1999), and L. bergylta is a protogynous hermaphrodite (Dipper 151 and Pullin 1979) and the only of the four species used for Fp estimations that lays its 152 demersal eggs into algae nests (Artüz 2005) (Table 1). Spawning periods are typically in 153 summer, except for L. bergylta (winter; Villegas-Ríos et al. 2014) and D. sargus 154 (spring/beginning of summer; Morato et al. 2003). No large scale migrations across reefs for 155 aggregating in high numbers at a given place and time (i.e. spawning aggregations) are 156 known for any of the species. They all are benthic fishes, have small to medium home 157 ranges/yearly displacement, and the majority is territorial (Claudet et al. 2010). 
160 Only fish counts from the main sampling period ('summer' months, June to November, 354

161 transects) were used for model building (i.e. model fitting data set) to account for an unequal

162 seasonal sampling effort. Eleven environmental variables were available for modeling the

163 spawning biomass and potential fecundity of reef fishes, including depth, slope, slope of the

164 slope (Pittman et al. 2009), distance to coast, main bottom type (sediment or rock), distance

165 to nearest sediment, distance to nearest rock, ruggedness, exposure to currents, exposure to

166 ocean swell, and concentration of Chlorophyll a (see Table 2 in Schmiing et al. 2013).

167 Accurate data exploration, following Zuur et al. $(2007,2010)$, was applied to the model

168 fitting data set and included analyses of homogeneity, potential outliers, Cleveland dotplots,

169 pairplots, boxplots and frequency plots. Spatial independency was evaluated with variograms

170 but only for shorter distances $(<1000 \mathrm{~m})$ to avoid possible land intersections. Variance

171 Inflation Factor (VIF) analysis and Spearman rank correlations were used to test

172 (multi)collinearity, while (stepwise) removing variables with a VIF higher than 3 and

173 pairwise correlations of rho $<-0.5$ and $>0.5$. Data exploration resulted in a final set of five

174 explanatory variables: 1) depth - mean transect depth in meters, measured in situ; 2) slope -

175 mean seafloor steepness in degrees, estimated via a bathymetric grid in a geographic

176 information system (GIS); 3) distance to sediment - mean distance in meters to the nearest

177 soft bottom as estimated in a GIS; (4) exposure to current - relative exposure derived from a

178 shallow-water oceanographic current model (percentage of the maximum; Tempera 2008;

179 Tempera et al. 2012); and 5) exposure to swell - relative exposure derived from a GIS-based

180 fetch analysis (percentage of the maximum; Tempera 2008; Tempera et al. 2012). Distance to

181 sediment was log transformed (base 10, adding the constant 1 because of zero values) and

182 exposure to current square root transformed because data exploration revealed extreme

183 observations and non-normality. A detailed description of the environmental variables and

184 the data exploration is given in Schmiing et al. (2013). 
185 We used generalized additive models for location, scale and shape (GAMLSS, gamlss 186 package, version 4.1-2; Rigby and Stasinopoulos 2005) with a zero adjusted gamma 187 distribution (ZAGA) to model the (non-linear) relationship between the response and 188 environmental variables. This distribution is appropriate for modeling response variables with 189 positive values but also admits zeros. It is a three parameter distribution (mu, sigma, nu) for 190 which we first modeled mu (mean of the response variable) and then nu (probabilities at zero) 191 as a function of the environmental variables while applying stepwise backward model 192 selection based on the minimization of the Aikake's Information Criterion (AIC) and 193 Schwarz Bayesian Criterion (SBC). As a result, the mu and nu parameter may have different 194 combinations of environmental variables. It was not necessary to model the sigma parameter 195 for any response variable. We used penalized b-splines (Eilers and Marx 1996) that 196 automatically estimated the smoothing parameter and thus the degrees of freedom via 197 Maximum Likelihood. Variable selection and smoother estimates were confirmed with 198 graphical analyses and smoothers that constantly included zero in the confidence interval 199 were excluded (Wood and Augustin 2002). If smoothers indicated a straight line, parametric 200 terms were used in the GAMLSS instead of smoothing functions.

201 No GAMLSS could be produced for the spawning biomass of L. bergylta, S. atricauda, and $202 S$. caeruleus because model validation revealed violation of underlying statistical 203 assumptions (i.e. residual patterns and heterogeneity, see below). Consequently, data were 204 transformed to presence-absence of mature individuals and generalized additive models 205 (GAMs) with a binomial error distribution, thin plate regression splines and automatic 206 smoothness selection were applied (mgcv package, version 1.5-5; Wood 2004). To avoid 207 potential overfitting, the upper limit of the degrees of freedom associated with a smooth term 208 was fixed, if applicable (i.e. explanatory variable current in GAMs of L. bergylta and S. 209 cretense). 
210 Model validation considered i) the graphical analyses of residuals, including density plots,

211 normal Q-Q plots, worm plots (detrended QQ plots; van Buuren and Fredriks 2001),

212 detrended transformed Owen's plot (dtop; Owen 1995), and plots of residuals versus fitted

213 values, each predictor, and spatial coordinates; ii) summary statistics of residuals (mean,

214 variance, skewness, kurtosis, and Filliben correlation coefficient; Rigby and Stasinopoulos

215 2005; Stasinopoulos and Rigby 2007); and iii) calculation of receiver operating characteristic

216 (ROC) curves and the area under the curve (AUC) for binomial models. Potential outliers, as

217 revealed by model validation, were removed and the modeling process was repeated, if

218 applicable. In addition, winter data (December to May, 108 transects) from the same study

219 area and sampling period were used as validation data set to test the model generality, after

220 applying a Mann-Whitney-test to examine differences between winter and summer data

221 (Schmiing et al. 2013). The Spearman's rank correlation (Rho) between predicted and

222 observed values was calculated for the model fitting and validation data set. All analyses

223 were performed with the software R (version 2.14.1; R Development Core Team 2011).

Spatial patterns of the reproductive potential

226 Validation of the final models was positive and thus results were used to predict the spawning

227 biomass (Ws) and potential fecundity (Fp) over the entire study area on a $5 \mathrm{~m}$ grid for each

228 species. Results were imported into a GIS (ArcGIS 10 CESRI) for visualization and further

229 analyses. Predicted values of continuous response variables (ZAGA GAMLSS) were set i)

230 equal to the maximum observed value of biomass or fecundity if this was exceeded (i.e. to

231 mitigate possible overestimation), or ii) to zero if they were lower than the minimum

232 observed fecundity or, respectively, the minimum weight of a single medium sized individual

233 (i.e. to mitigate possible underestimation). Values were then converted to a relative scale (the

234 ratio of a given predicted value to the maximum prediction) to compare individual species 
235 with different reproductive strategies (adapted from Schmiing et al. 2013). Predictions of 236 binomial models were on a logit scale from 0 to 1 . There are different approaches for 237 determining thresholds that convert the probabilities to presence/absence. We used the 'equal 238 sensitivity and specificity' approach that has been shown to achieve good results (Liu et al. 239 2005), acknowledging that the choice is essentially arbitrary. This approach finds the 240 threshold where positive observations are just as likely to be wrong as negative observations.

241 We 1) identified areas containing a minimum of $1 \%, 10 \%, 25 \%$ and $50 \%$ of the maximum 242 predicted spawning biomass $\left(\mathrm{Ws}_{1}, \mathrm{Ws}_{10}, \mathrm{Ws}_{25}, \mathrm{Ws}_{50}\right)$ or potential fecundity $\left(\mathrm{Fp}_{1}, \mathrm{Fp}_{10}, \mathrm{Fp}_{25}\right.$, $243 \mathrm{Fp}_{50}$ ) of each species (adapted from Schmiing et al. 2013), and 2) calculated the percentage of 244 rocky reef habitat that was potentially suitable for these four different target levels of Ws and 245 Fp ('single-species reproductive habitats', RH). Results of binomial models (GAM) were 246 integrated in this analysis by identifying areas where the probability of occurrence was higher 247 than the species-specific threshold. Finally, we calculated the representativeness of these 248 areas in the existing MPA network (i.e. percentage integrated).

249 In addition, we identified 'multi-species RHs' as areas where the reproductive metrics had 250 overlapping high-values: $\mathrm{Ws}_{\mathrm{com} / \text { all }} \mathrm{RHs}$ have a minimum of $10 \%$ relative spawning biomass 251 only of commercial species ('com') or commercial and non-commercial species ('all'), 252 respectively. $\mathrm{Fp}_{\text {com }} \mathrm{RHs}$ consider areas with a minimum of $10 \%$ relative potential fecundity 253 of commercial species (adapted from Schmiing et al. 2013). Multi-species RHs were either 254 fisheries related and considered the spawning biomass and potential fecundity of the four 255 commercial species (D. sargus, L. bergylta, S. atricauda, S. cretense) ( $\mathrm{Ws}_{\mathrm{com}}$ and Fp $\left.\mathrm{p}_{\text {com }} \mathrm{RHs}\right)$ 256 or considered the predicted spawning biomass of all eight species to analyze the protection of 257 (fish) biodiversity ( $\mathrm{Ws}_{\text {all }} \mathrm{RHs}$ ). Predictions for binomial models (the occurrence of mature $L$. 258 bergylta and S. cretense) were included by selecting all sites with a predicted probability 259 above the species-specific identified threshold that overlapped with $\mathrm{Ws}_{10}$. We calculated the 
260 amount of rocky reef habitat potentially suitable as multi-species $\mathrm{RH}$ and evaluated the

261 representativeness of these sites by calculating their percentage inside the existing MPA

262 network. We acknowledge that any definition of potential RHs is arbitrary and other criteria

263 or thresholds may be reasonable too.

264

265 Results

266 Predictive models

267 We modeled the potential spawning biomass of five species (A. luridus, C. julis, D. sargus, $S$. 268 salpa, S. atricauda), the probability of occurrence of mature individuals of three species $(L$.

269 bergylta, S. cretense, S. caeruleus), and the potential fecundity of mature females of four

270 commercial species (D. sargus, L. bergylta, S. atricauda, S. cretense) (see online

271 supplementary material, Table $\mathrm{S}^{1}{ }^{1}$ ). Final models complied with central statistical

272 assumptions (i.e. model residuals did not show any patterns, heterogeneity, or dependence,

273 and were approximately normally distributed) as indicated by plots and summary statistics

274 (not shown). The average correlation between predicted and observed values of the model

275 building and validation data set, respectively, was higher than 0.5 , indicating reasonable

276 robust model fitting and generalization (online supplementary material, Table S2 ${ }^{1}$ ). A

277 significant difference between group medians of the model fitting and validation data set (i.e.

278 lower values in winter) was only detected for the spawning biomass of A. luridus, C. julis,

279 and $S$. cretense.

280 The minimum AUC value for binomial models was 0.84 , indicating excellent model fitting

281 (Table S2 ${ }^{1}, 0.8 \leq \mathrm{AU}^{1} \mathrm{C}<0.9$; Hosmer and Lemeshow 2000). Smoother estimates of

282 GAMLSS and GAMs are provided in the supplementary material (Figs. S1-S3 ${ }^{1}$ ) and show

283 species-specific patterns (Figs. $\mathrm{S} 1-\mathrm{S}^{1}{ }^{1}$ ). The mu parameter estimate for the explanatory

\footnotetext{
${ }^{1}$ Supplementary data are available with the article on the journal Web site at: XX
} 
284

285

variable depth in the biomass model of $S$. salpa was not significant but the variable was retained in the model because zero was not continuously included in the confidence interval of the smoother (Fig. S2 ${ }^{1}$; Wood and Augustin 2002). Instead, the smoother was similar to significant smoothers of other models for this species (Schmiing et al. 2013) and the $\mathrm{AIC} / \mathrm{SBC}$ statistic increased if the variable was removed. The threshold for the presence of mature individuals, as modeled by binomial GAMs, was 0.34 for L. bergylta and S. caeruleus and 0.55 for $S$. cretense, respectively (Table 2 ).

\section{Spatial patterns of the reproductive potential - single species}

Predictive distribution maps of the relative spawning biomass and relative potential fecundity show distinct spatial patterns across the study area (Figs. 2-3). Depth and distance to sediment significantly shaped patterns of all metrics (supplementary material, Table S1, Figs. $\mathrm{S} 1-\mathrm{S} 3^{1}$ ), whereas biomass and fecundity typically increased (non-linearly) with increasing depth and distance to sediment. (Figs. S1-S $3^{1}$ ).

Mature individuals of L. bergylta, S. caeruleus and S. cretense were predicted to occur in about half of the available reef habitat (Table 2). Minimum levels of relative spawning biomass or fecundity of single species, i.e. presence, were predicted for almost the entire reef habitat, as expected $\left(\mathrm{Ws}_{1}: 91-100 \%\right.$ of the hard-bottom in the study area, $\mathrm{Fp}_{1}: 80-100 \%$; Figs. 2-4), but the amount of suitable habitat decreased steeply when considering higher targets of the reproductive potential ( $\mathrm{Ws}_{10}$ to $\mathrm{Ws}_{50}$, and $\mathrm{Fp}_{10}$ to $\mathrm{Fp}_{50}$; Fig. 4). Habitats with target level $\mathrm{Ws}_{10}$ or $\mathrm{Fp}_{10}$ were predicted to cover more than $50 \%$ of the reefs, except for the fecundity of S. cretense, whereas habitats with target $\mathrm{Ws}_{50}$ or $\mathrm{Fp}_{50}$ typically encompassed less than $10 \%$ (Fig. 4). 59-90\% of these single species RHs, or reefs with predicted presence of mature individuals, were represented inside the existing MPA network (Table 2, Fig. 4). 
310 Potential RHs with high spawning biomass of commercial species (i.e. areas containing 10\%

311 of the predicted spawning biomass of all commercial species, $\mathrm{Ws}_{\mathrm{com}} \mathrm{RHs}$ ) were distributed

312 across the entire study area and covered $18 \%$ of the reef habitat (Figs. 4-5). If all study

313 species were considered, disregarding their commercial use $\left(\mathrm{Ws}_{\text {all }}\right)$, RHs fell inside the $\mathrm{Ws}_{\text {com }}$

314 RHs of commercial species and had about half their size (Fig. 4). Modeled RHs with high

315 fecundity of multi-species, Fp $p_{\text {com }}$ RHs, covered only $5 \%$ of the reef habitat and concentrated

316 at the north coast of Faial Island and north-west coast of Pico Island (Figs. 4-5). The only

317 larger overlap between $\mathrm{Ws}_{\text {com }}$ and $\mathrm{Fp}_{\text {com }}$ was at the north-west coast of Pico Island. The 318 majority of $\mathrm{Ws}_{\mathrm{com} / \mathrm{all}}$ and $\mathrm{Fp}_{\mathrm{com}} \mathrm{RHs}$ were located in the existing MPA network (74-91\%,

319 Figs. $4-5)$, where they represented $21 \%\left(\mathrm{Ws}_{\mathrm{com}}\right), 12 \%\left(\mathrm{Ws}_{\mathrm{all}}\right)$, and $7 \%\left(\mathrm{Fp}_{\text {com }}\right)$, respectively, 320 of the total protected reef habitat down to $40 \mathrm{~m}$.

\section{Discussion}

\section{Predictive models}

324 We modeled spatial patterns of the spawning biomass and potential fecundity of eight reef

325 fishes and identified reef areas that likely supported fish populations with high reproductive 326 potential. Modeling results concord with other studies that show how bathymetry, exposure to 327 oceanographic forces, and distance to habitat edges significantly affect the distribution of reef 328 fishes (Friedlander et al. 2003; Beger and Possingham 2008; Schmiing et al. 2013). Fish 329 biomass, for example, is positively related to depth (Krajewski and Floeter 2011) and 330 negatively to exposure (Friedlander et al. 2003; Krajewski and Floeter 2011) or distance to 331 reef edges (Friedlander and Parrish 1998). Distance to sediment was the only variable that 332 significantly influenced reproductive patterns of all species, whereas all metrics typically 333 increased with increasing distance to sediment. 
334 Overall, models performed well in the validation, even with data from another season.

335 Optimally, however, the validation data should be spatially independent (Araújo and Guisan 336 2006), but such information was not available. Spawning (reproductively active) periods of 337 study species were typically included in the data used for modeling, except for L. bergylta 338 which spawn earlier (Villegas-Ríos et al. 2014) and D. sargus for which only part of the 339 spawning season (Morato et al. 2003) was integrated. No significant differences, however, 340 were found between data from winter and summer for these species. More importantly, no 341 seasonal changes in spatial patterns, such as large scale migrations during the spawning 342 season are known for any of the modeled species. Only D. sargus expands its home range 343 slightly and increases the frequency of forays during the reproductive season, yet no evidence 344 for spawning aggregations exists (Abecasis et al. 2015a). However, it could be considered the 345 only species for which a reproduction related spatial behavior may influence the outcomes of 346 the modeled reproductive habitats.

\section{Spatial distribution of the reproductive potential}

349 Predictive maps were used to identify sites with potentially high reproductive output. We argue that the spatial distribution of RHs is independent of the legal protection status in the

351 present study, but rather influenced by environmental conditions. Studied MPAs are not 352 effectively implemented: management plans are missing, only limited resources exist for 353 enforcement and long-term monitoring, and compliance is low (Schmiing et al. 2014a; 354 Abecasis et al. 2015b; Afonso et al., unpubl. data). No significant influences on exploited 355 populations are observed (Schmiing et al. 2014a; Afonso et al., unpubl. data) and the single, small no-take area at the south-east tip of Faial Island is unlikely to achieve significant multi-

357 species conservation goals because of its limitation (Abecasis et al. 2015b). Instead, highest 358 fishing effort is even observed inside the protected areas (Diogo and Pereira 2013; Schmiing 
et al. 2015). We thus argue that the present situation has to be distinguished from well-

360 functioning MPAs that support denser fish populations with larger individuals ('reserve

361 effect'; Lester et al. 2009) and, as consequence, most likely would encompass RHs. Instead,

362 the present approach can be used as a priori study with the additional benefit of testing newly

363 declared but yet unimplemented MPAs. It may also be used in support of a (potential)

364 revision of a MPA network. In this context, predictive maps are a powerful and easy

365 understandable tool for decision support and marine management (Sundblad et al. 2011;

366 Schmiing et al. 2013).

367 In general, spatial patterns of fecundity and spawning biomass of most study species were

368 similar (i.e. the location and size of areas with higher and lower values of both metrics were

369 comparable for individual species). This contradicts the expectation that potential fecundity

370 would be a refinement of spawning biomass (i.e. representing a narrower area) because it

371 considers both the maturity and sex of a specimen. The situation appears reversed for $L$.

372 bergylta where the probability of occurrence for spawning biomass seems narrower than for

373 fecundity. Probably, this is an artefact of using presence/absence data instead of continuous

374 biomass values, which turns direct comparisons between both reproductive metrics difficult.

375 However, if true hermaphrodites (digynic, protogynous, simultaneous) have comparable

376 spatial patterns for spawning biomass and potential fecundity, one of the two metrics can be

377 chosen for analyzing the reproductive potential. The spawning biomass might be preferential

378 for non-invasive methods such as UVCs. Identifying mature specimens, for example via size

379 estimates, is more practicable than identifying mature females if sex-determination via 380 distinct color morphs does not apply. Analyzing fecundity, however, seems advisable for

381 male-dominated populations, such as S. cretense. Fecundity models are solely based on

382 female counts and, as expected, all target levels of this reproductive metric $\left(\mathrm{Fp}_{10 / 25 / 50}\right)$ are

383 spatially more constrained than the distribution of mature males and females (i.e. spawning 
384 biomass). The complex mating system of $S$. cretense, including territorial, haremic males or 385 multi-male groups (Afonso et al. 2008) and the highly skewed sex ratio (i.e. male dominated, 386 average sex ratio 1:0.45 \pm 0.13 ) are probably causing the observed precision of its Fp RHs.

387 Predicted multi-species RHs of commercial species, $\mathrm{Ws}_{\mathrm{com}} / \mathrm{Fp}_{\mathrm{com}}$, were much smaller than 388 anticipated. The $\mathrm{Fp}_{\mathrm{com}} \mathrm{RHs}$, for example, covered 5\% of the rocky habitat, which probably is 389 driven by the restricted distribution of Fp RHs of $S$. cretense. Reproductive habitats of 390 spawning biomass that include all eight modeled species, $\mathrm{Ws}_{\text {all }}$, fall completely inside the $391 \mathrm{Ws}_{\text {com }}$ RHs. This is a general consequence of the method used for RH identification (i.e. 392 negative relation between the size of multi-species RHs and the number of integrated 393 species), especially if species have small overlapping habitats and different life histories

394 (Claudet et al. 2010; Schmiing et al. 2013). Alternatively, other methods than a simple spatial 395 overlay of individual species maps may be used, such as an additive or complementarity 396 approach (Schmiing et al. 2015). The presented approach for identifying RHs works well for 397 reef fish with smaller home ranges and no significant movement between habitats for 398 reproduction. If such seasonal movements occur, sampling design and modeling would have 399 to be adjusted accordingly.

\section{Implications for marine conservation planning}

402 The reproductive output is the first of several processes for determining connectivity among 403 populations (Cowen and Sponaugle 2009; Treml et al. 2012), whereas the likelihood of larval 404 subsidy to adjacent (un)protected areas is low or insignificant if the reproductive output is 405 low (or null). Although the opposite is not necessarily true, we argue that single- and multi406 species RHs, either defined by spawning biomass or potential fecundity, are potentially good 407 larval sources that, in addition to adult movement, may contribute to replenish and sustain 
408 natal and neighboring areas and populations (Underwood et al. 2013). Such source habitats

409 are the 'key' to persisting, viable fish populations (Figueira and Crowder 2006).

410 The rate of successful larval settlement and recruitment to adjacent (or natal) populations,

411 however, is variable and also depends on a variety of biotic, abiotic and physical factors

412 (Christie et al. 2010). Larval behavior, larval survival, the availability of suitable settlement

413 habitat, and post-settlement survival contribute to connectivity patterns and can also modify

414 initial recruitment patterns after settlement (White and Caselle 2008; Cowen and Sponaugle

415 2009; Felix-Hackradt et al. 2013). Ocean circulations and currents shape connectivity

416 patterns between source and sink areas and determine the extent of local retention and self-

417 seeding (Cowen 2002; Di Franco et al. 2012). West and northwest swells predominate in the

418 study area, whereas the western tip of the Faial and the channel between Faial and Pico

419 Islands experience strongest swell and current (Carvalho 2003; Tempera 2008; Tempera et al.

420 2012). Hydrodynamic conditions might support distribution of potential recruits from the

421 RHs to sites with higher potential for larval retention, such as at the south coast of Faial

422 Island (Fontes et al. 2009a, 2009b). However, more research is needed to study larval

423 distribution and recruitment in the region. First studies from the same region confirmed

424 multiple natal signatures (i.e. different larval sources), even in sites where most signatures

425 were consistent with self-recruitment (i.e. south coast of Faial; Fontes et al. 2009b). Self-

426 recruitment, in general, probably is more common than previously perceived (e.g., Almany et

427 al. 2007; Berumen et al. 2012; Treml et al. 2012). Some studies show that the success of

428 larval transport also depends on the PLD and typically decreases with longer PLDs (Koeck et

429 al. 2015). Other studies, on the contrary, highlight the importance of larval behavior,

430 swimming and sensory abilities (Lecchini et al. 2005; Cowen and Sponaugle 2009; Soeparno

431 et al. 2013). D’Aloia et al. (2015) estimated dispersal kernels based on genetic parentage

432 analyses, and showed that dispersal declines exponentially with distance but is unrelated to 
433 PLD. Thus, small spacing distances between protected sites, such as in Faial Island, likely 434 promote larval connectivity (Almany et al. 2007; Fontes et al. 2009b; Green et al. 2014). 435 Nonetheless, MPA size rather than spacing between MPAs is likely to have a 436 disproportionate effect on densities of commercially targeted fish (Claudet et al. 2008; 437 Moffitt et al. 2011).

438 The overall good representativeness of single and multi-species RHs inside the studied MPA 439 network largely supports the existing site selection. Representativeness is above commonly 440 recommended targets of 20 to 40\% (World Parks Congress 2003; Green et al. 2014), but 441 more than half of the reef habitat is anyway integrated in the MPAs, relativizing this 442 percentage. Furthermore, multi-species RHs represent only $7 \%\left(\mathrm{Fp}_{\text {com }}\right)$ to $21 \%\left(\mathrm{Ws}_{\text {com }}\right)$ of the 443 entire protected reef habitat until $40 \mathrm{~m}$ depth. Certain RHs, such as the $\mathrm{Fp}_{\text {com }} \mathrm{RH}$ on the north 444 coast of Faial, are mostly unprotected. Considering that often only a limited amount of 445 resources is available for marine conservation (Abecasis et al. 2015b), or only a limited 446 amount of habitat can be protected, this RH might be a strategic site for protection to enhance 447 population persistence and larval subsidy and, ultimately, fisheries. Further research is 448 needed to quantify the role for larval dispersal of this RH (and others). Nevertheless, 449 protection of potential source habitats instead of random or 'sink' habitats is more likely to 450 promote connectivity and support adjacent fisheries and, consequently, should be encouraged 451 (Crowder et al. 2000). For example, simulations showed that protecting $10-20 \%$ of the sites 452 with highest spawning biomass could lead to increased abundances and harvest of the coral 453 trout in the Great Barrier Reef, Australia (Bode et al. 2012). On the contrary, failing 454 protection and selective removal of large, mature individuals by fishing may alter genetic 455 variability and/or sex ratios, and reduce the reproductive potential of a population (e.g., 456 Birkeland and Dayton 2005; Laugen et al. 2014). In summary, overall site selection of the 457 studied MPAs seems adequate if considering the distribution of RHs. It is, however, beyond 
458 the scope of this study to deliver new conservation scenarios (but see Schmiing et al. (2015)

459 who provide alternative solutions for site selection, integrating also the information of RHs).

460 Nevertheless, certain conditions have yet to be met so that benefits for biodiversity and

461 fisheries may arise by protecting RHs, including 1) efficient conservation measures (i.e., no-

462 take reserves), 2) implementation of management plans, and 3) improved compliance of rules

463 and appropriate enforcement (Abecasis et al. 2015b).

464 Despite the importance of other factors that influence larval subsidy and recruitment, we 465 argue that analyzing connectivity surrogates, such as spawning biomass and potential 466 fecundity, can be particularly useful when information about in situ larval sources, larval 467 dispersal and connectivity is absent or the necessary information to model such processes is 468 missing (this study; Bode et al. 2012). Nevertheless, gathering and incorporating accurate 469 data of local connectivity patterns should be encouraged. Identifying RHs can be seen as a 470 first step for site selection to identify key areas that potentially protect connectivity and 471 benefit adjacent fisheries. In addition, a multitude of other factors have to be considered in 472 marine spatial planning, including a diverse set of biological/ecological features, socio473 economic aspects, conservation objectives, and climate change (Andrello et al. 2015; Beger 474 et al. 2015; Schmiing et al. 2015).

476 In conclusion, the present study showed that spatial patterns of spawning biomass and 477 potential fecundity are species-specific, heterogeneous, and influenced by distance to the 478 habitat edge, bathymetry, and exposure to current or swell. Spatial patterns of the 479 reproductive metrics seem to be similar for simultaneous hermaphrodites or female 480 dominated populations. On the contrary, if females are underrepresented, considering the sex 481 (i.e. fecundity) can refine predictions of reproductive spatial patterns based on the mature, 482 spawning biomass of all specimens. Studied surrogates may assist site selection of MPAs. 
483 We propose areas with increased reproductive output as potentially good larval sources and 484 their protection should be encouraged to optimize MPA connectivity and ecologically 485 functioning. The studied MPA network has potential to benefit fisheries/conservation but 486 further progress is needed to ensure an effective implementation. The rather simple approach 487 presented here works well for sedentary species and can support adaptive management and 488 MPA design. Predictions and resulting maps of the reproductive potential are essential for systematic conservation planning, and can be used in stakeholder meetings, MPA evaluation and adaptive management (Sundblad et al. 2011; Schmiing et al. 2014b, 2015). We propose to integrate this or similar methods as a first step of a manifold process for identifying potential sources of recruitment subsidies and priority sites for conservation.

493

\section{Acknowledgements}

495 We wish to thank all SCUBA divers who participated in data collection during fish surveys.

496 Two anonymous reviewers and the associate editor provided constructive and helpful 497 comments on an earlier draft. Individual financial support of MS was given by the European 498 Marie Curie Research Training Network FREESUBNET (MRTN-CT-2006-036186), the 499 Portuguese Foundation for Science and Technology (FCT, SFRH/BD/66117/2009) and the 500 Regional Fund for Science and Technology (FRCT, M3.1.5/F/168/2012). Field research was 501 conducted in the scope of projects CLIPE (FCT - Praxis XXI/3/3.2/EMG/1957/95), MARÉ 502 (LIFE B4-3200/98-509), MAREFISH (FCT-POCTI/BSE/41207/2001), OGAMP 503 (INTERREG IIIb/MAC/4.2/A2 2001) and MARMAC (INTERREGIIIb-03/MAC/4.2/A1 504 2004). This publication is a contribution to the project MoniZEC (M2.1.2/I/018/2011). 505

\section{References}


507 Abecasis, D., Afonso, P., and Erzini, K. 2015a. Changes in movements of white seabream

508 (Diplodus sargus) during the reproductive season. Estuar. Coast. Shelf. 167: 499-503.

509 Abecasis, R.C., Afonso, P., Colaço, A., Longnecker, N., Clifton, J., Schmidt, L., and Santos,

510 R.S. 2015b. Marine conservation in the Azores: evaluating marine protected area

511 development in a remote island context. Front. Mar. Sci. 2: 104.

512 Afonso, P., Morato, T., and Santos, R.S. 2008. Spatial patterns in reproductive traits of the 513 temperate parrotfish Sparisoma cretense. Fish. Res. 90: 92-99.

514 Afonso, P., Fontes, J., Holland, K.N., and Santos, R.S. 2009. Multi-scale patterns of habitat 515 use in a highly mobile reef fish, the white trevally Pseudocaranx dentex, and their 516 implications for marine reserve design. Mar. Ecol. Prog. Ser. 381: 273-286.

517 Almany, G.R., Berumen, M.L., Thorrold, S.R., Planes, S., and Jones, G.P. 2007. Local

518 replenishment of coral reef fish populations in a marine reserve. Science 316: 742-744.

519 Andrello, M., Mouillot, D., Somot, S., Thuiller, W., and Manel, S. 2015. Additive effects of

520 climate change on connectivity between marine protected areas and larval supply to fished 521 areas. Divers. Distrib. 21: 139-150.

522 Araújo, M.B., and Guisan, A. 2006. Five (or so) challenges for species distribution 523 modelling. J. Biogeogr. 33: 1677-1688.

524 Artüz, M.L. 2005. Embryonic and larval development of the ballan wrasse Labrus bergylta 525 (Ascanius 1767). Hidrobiologica 10: 98-101.

526 Beger, M., and Possingham, H.P. 2008. Environmental factors that influence the distribution 527 of coral reef fishes: modeling occurrence data for broad-scale conservation and management. 528 Mar. Ecol. Prog. Ser. 361: 1-13.

529 Beger, M., McGowan, J., Treml, E.A., Green, A.L., White, A.T., Wolff, N.H., Klein, C.J., 530 Mumby, P.J., and Possingham, H.P .2015. Integrating regional conservation priorities for 531 multiple objectives into national policy. Nat. Commun. 6: 8208. 
532 Berkeley, S.A., Hixon, M.A., Larson, R.J., and Love, M.S. 2004. Fisheries sustainability via 533 protection of age structure and spatial distribution of fish populations. Fisheries 29(8): 23-32.

534 Berumen, M.L., Almany, G.R., Planes, S., Jones, G.P., Saenz-Agudelo, P., and Thorrold, 535 S.R. 2012. Persistence of self-recruitment and patterns of larval connectivity in a marine 536 protected area network. Ecol. Evol. 2(2): 444-452. doi: 10.1002/ece3.208.

537 Birkeland, C., and Dayton, P.K. 2005. The importance in fishery management of leaving the 538 big ones. Trends Ecol. Evol. 20(7): 356-358.

539 Bode, M., Armsworth, P.R., Fox, H.E., and Bode, L. 2012. Surrogates for reef fish 540 connectivity when designing marine protected area networks. Mar. Ecol. Prog. Ser. 466: 155541166.

542 Botsford, L.W., Brumbaugh, D.R., Grimes, C., Kellner, J.B., Largier, J., O’Farrell, M.R., 543 Ralston, S., Soulanille, E., and Wespestad, V. 2009. Connectivity, sustainability, and yield: 544 bridging the gap between conventional fisheries management and marine protected areas. 545 Rev. Fish Biol. Fisher. 19: 69-95.

546 Calado, H., Lopes, C., Porteiro, J., Paramio, L., and Monteiro, P. 2009. Legal and technical 547 framework of Azorean Protected Areas. J. Coastal Res., SI 56: 1179-1183.

548 Calado, H., Ng, K., Lopes, C., and Paramio, L. 2011. Introducing a legal management 549 instrument for offshore marine protected areas in the Azores-The Azores Marine Park. 550 Environ. Sci. Policy 14: 1175-1187. doi: 10.1016/j.envsci.2011.09.001.

551 Carvalho, F. 2003. Elementos do clima de agitação marítima no Grupo Central dos Açores 552 (Mar Alto) (in Portuguese). Instituto de Meteorologia, Lisboa, Portugal.

553 Christie, M.R., Tissot, B.N., Albins, M.A., Beets, J.P., Jia, Y., Ortiz, D.M., Thompson, S.E., 554 and Hixon, M.A. 2010. Larval connectivity in an effective network of marine protected areas. 555 PLoS ONE 5(12): e15715. 
556 Claudet, J., Osenberg, C.W., Benedetti-Cecchi, L., Domenici, P., Garcia-Charton, J.-A.,

557 Perez-Ruzafa, A., Badalamenti, F., Bayle-Sempere, J., Brito, A., Bulleri, F., Culioli, J.-M.,

558 Dimech, M., Falcon, J.M., Guala, I., Milazzo, M., Sanchez-Meca, J., Somerfield, P.J.,

559 Stobart, B., Vandeperre, F., Valle, C., and Planes, S. 2008. Marine reserves: size and age do

560 matter. Ecol. Lett. 11(5): 481-489. doi: 10.1111/j.1461-0248.2008.01166.x.

561 Claudet, J., Osenberg, C.W., Domenici, P., Badalamenti, F., Milazzo, M., Falcón, J.M.,

562 Bertocci, I., Benedetti-Cecchi, L., Garcia-Charton, J.A., Goñi, R., Borg, J.A., Forcada, A., De

563 Lucia, G.A., Perez-Ruzafa, A., Afonso, P., Brito, A., Guala, I., Le Direach, L., Sanchez-

564 Jerez, P., Somerfield, P.J., and Planes, S. 2010. Marine reserves: fish life history and

565 ecological traits matter. Ecol. Appl. 20: 830-839.

566 Costello, C., Rassweiler, A., Siegel, D., De Leo, G., Micheli, F., and Rosenberg, A. 2010.

567 The value of spatial information in MPA network design. Proc. Natl. Acad. Sci. USA

568 107(43): 18294-18299. doi: 10.1073/pnas.0908057107.

569 Cowen, R.K. 2002. Larval dispersal and retention and consequences for population

570 connectivity. In Coral reef fishes; dynamics and diversity in a complex ecosystem. Edited by

571 P.F. Sale. Academic Press, San Diego, CA, pp. 171-200.

572 Cowen, R.K., and Sponaugle, S. 2009. Larval dispersal and marine population connectivity.

573 Ann. Rev. Mar. Sci. 1: 443-466.

574 Crowder, L.B., Lyman, S.J., Figueira, W.F., and Priddy, J. 2000. Source-sink population

575 dynamics and the problem of sitting marine reserves. B. Mar. Sci. 66(3): 799-820.

576 D'Aloia, C.C., Bogdanowicz, S.M., Francis, R.K., Majoris, J.E., Harrison, R.G., and Buston,

577 P.M. 2015. Patterns, causes, and consequences of marine larval dispersal. P. Natl. Acad. Sci.

578 USA 112(45): 13940-13945. doi: 10.1073/pnas.1513754112. 
579 De Girolamo, M., Scaggiante, M., and Rasotto, M.B. 1999. Social organization and sexual 580 pattern in the Mediterranean parrotfish Sparisoma cretense (Teleostei: Scaridae). Mar. Biol. 581 135: $353-360$.

582 Di Franco, A., Gillanders, B.M., De Benedetto, G., Pennetta, A., De Leo, G.A., and Guidetti, 583 P. 2012. Dispersal patterns of coastal fish: Implications for designing networks of marine 584 protected areas. PLoS ONE 7(2): e31681. doi:10.1371/journal.pone.0031681.

585 Dipper, F.A., and Pullin, R.S.V. 1979. Gonochorism and sex-inversion in British Labridae 586 (Pisces). J. Zool. 187: 97-112.

587 Diogo, H., and Pereira, J.G. 2013. Recreational boat fishing pressure on fish communities of 588 the shelf and shelf-break of Faial and Pico Islands (Azores Archipelago): implications for 589 coastal resource management. Acta Ichthyol. Pisc. 43: 267-276.

590 Diogo, H., Pereira, J.G., and Schmiing, M. 2015. Catch me if you can: Non-compliance of 591 limpet protection in the Azores, Mar. Policy 63: 92-99.

592 Eilers, P.H.C., and Marx, B.D. 1996. Flexible smoothing with B-splines and penalties (with 593 comments and rejoinder). Stat. Sci. 11: 89-121.

594 Felix-Hackradt, F.C., Hackradt, C.W., Trevino-Oton, J., Perez-Ruzafa, A., and Garcia595 Charton, J.A. 2013. Temporal patterns of settlement, recruitment and post-settlement losses 596 in a rocky reef fish assemblage in the South-Western Mediterranean Sea. Mar. Biol. 160(9): 597 2337-2352. doi: 10.1007/s00227-013-2228-2.

598 Figueira, W.F., and Crowder, L.B. 2006. Defining patch contribution in source-sink 599 metapopulations: the importance of including dispersal and its relevance to marine systems. 600 Popul. Ecol. 48(3): 215-24.

601 Fontes, J., Caselle, J.E., Afonso, P., and Santos, R.S. 2009a. Multi-scale recruitment patterns 602 and effects on local population size of a temperate reef fish. J. Fish Biol. 75: 1271-1286. 
603 Fontes, J., Caselle, J.E., Sheehy, M.S., Santos, R.S., and Warner, R.R. 2009b. Natal 604 signatures of juvenile Coris julis in the Azores: investigating connectivity scenarios in an 605 oceanic archipelago. Mar. Ecol. Prog. Ser. 387: 51-59.

606 Friedlander, A.M., and Parrish, J.D. 1998. Habitat characteristics affecting fish assemblages 607 on a Hawaiian coral reef. J. Exp. Mar. Biol. Ecol. 224: 1-30.

608 Friedlander, A.M., Brown, E.K., Jokiel, P.L., Smith, W.R., and Rodgers, K.S. 2003. Effects 609 of habitat, wave exposure, and marine protected area status on coral reef fish assemblages in 610 the Hawaiian archipelago. Coral Reefs 22: 291-305.

611 García-Díaz, M.M., Lorente, M.J., González, J.A., and Tuset, V.M. 2002. Morphology of the 612 ovotestis of Serranus atricauda (Teleostei, Serranidae). Aquat. Sci. 64: 87-96.

613 García-Díaz, M., González, J.A., Lorente, M.J., and Tuset, V.M. 2006. Spawning season, 614 maturity sizes, and fecundity in blacktail comber (Serranus atricauda) (Serranidae) from the 615 eastern-central Atlantic. Fish. B.-NOAA 104: 159-166.

616 Goñi, R., Adlerstein, S., Alvarez-Berastegui, D., Forcada, A., Reñones, O., Criquet, G., Polti, 617 S., Cadiou, G., Valle, C., Lenfant, P., Bonhomme, P., Pérez-Ruzafa, A., Sánchez-Lizaso, J.L., 618 García-Charton, J.A., Bernard, G., Stelzenmüller, V., and Planes, S. 2008. Spillover from six 619 western Mediterranean marine protected areas: evidence from artisanal fisheries. Mar. Ecol. 620 Prog. Ser. 366: 159-174.

621 Gonçalves, J.M.S., and Erzini, K. 2000. The reproductive biology of the two-banded sea 622 bream (Diplodus vulgaris) from the southwest coast of Portugal. J. Appl. Ichthyol. 16: 110623116.

624 Gonzáles, J.A., Lozano, I.J., and Hernández-Cruz, C.M. 1993. Fecundity of Sparisoma 625 (Euscarus) cretense (L.) (Osteichtyes, Scaridae) in the Canary Islands (in Spanish). Bol. Inst. 626 Esp. Oceanogr. 9(1): 123-131. 
627 Green, A., Smith, S.E., Lipsett-Moore, G., Groves, C., Peterson, N., Sheppard, S., Lokani, P., 628 Hamilton, R., Almany, J., Aitsi, J. and Bualia, L. 2009. Designing a resilient network of 629 marine protected areas for Kimbe Bay, Papua New Guinea, Oryx 43(4): 488-498. doi: $630 \quad 10.1017 / \mathrm{S} 0030605309990342$.

631 Green, A.L., Maypa, A.P., Almany, G.R., Rhodes, K.L., Weeks, R., Abesamis, R.A., 632 Gleason, M.G., Mumby, P.J., and White, A.T. 2014. Larval dispersal and movement patterns 633 of coral reef fishes, and implications for marine reserve network design. Biol. Rev. 90(4): 634 1215-1247. doi:10.1111/brv.12155.

635 Halpern, B.S. 2003. The impact of marine reserves: do reserves work and does reserve size 636 matter? Ecol. Appl. 13(1): S117-S137.

637 Harmelin-Vivien, M., Le Diréach, L., Bayle-Sempere, J., Charbonnel, E., García-Charton, 638 J.A., Ody, D., Pérez-Ruzafa, A., Reñones, O., Sánchez-Jerez, P., and Valle, C. 2008. 639 Gradients of abundance and biomass across reserve boundaries in six Mediterranean marine 640 protected areas: Evidence of fish spillover? Biol. Conserv. 141: 1829-1839.

641 Harrison, H.B., Williamson, D.H., Evans, R.D., Almany, G.R., Thorrold, S.R., Russ, G.R., 642 Feldheim, K.A., van Herwerden, L., Planes, S., Srinivasan, M., Berumen, M.L., and Jones, 643 G.P. 2012. Larval export from marine reserves and the recruitment benefit for fish and 644 fisheries. Curr. Biol. 22: 1023-1028.

645 Hosmer, D.W., and Lemeshow, S. 2000. Applied Logistic Regression. Second edition. Wiley 646 Series in Probability and Statistics, New York, USA.

647 Kelaher, B.P., Coleman, M.A., Broad, A., Rees, M.J., Jordan, A., and Davis, A.R. 2014.

648 Changes in fish assemblages following the establishment of a network of no-take marine 649 reserves and partially-protected areas. Plos One, 9(1), e85825-1-e85825-13. 
650 Klein, C. J., Chan, A., Kircher, L., Cundiff, A. J., Gardner, N., Hrovat, Z., Scholz, A., 651 Kendall, B.E., and Airamé, S. 2008. Striking a balance between biodiversity conservation and 652 socioeconomic viability in the design of marine protected areas. Conserv. Biol. 33: 691-700.

653 Koeck, B., Gerigny, O., Durieux, E.D.H., Coudray, S., Garsi, L.-H., Bisgambiglia, P.-A., 654 Galgani, F., and Agostini, S. 2015. Connectivity patterns of coastal fishes following different 655 dispersal scenarios across a transboundary marine protected area (Bonifacio strait, NW 656 Mediterranean). Estuar. Coast. Shelf. S. 154: 234-247.

657 Krajewski, J.P., and Floeter, S.R. 2011. Reef fish community structure of the Fernando de 658 Noronha Archipelago (Equatorial Western Atlantic): the influence of exposure and benthic 659 composition. Environ. Biol. Fish. 92: 25-40.

660 Lagabrielle, E., Crochelet, E., Andrello, M., Schill, S.R., Arnaud-Haond, S., Alloncle, N., and 661 Ponge, B. 2014 Connecting MPAs - eight challenges for science and management. Aquatic 662 Conserv.: Mar. Freshw. Ecosyst. 24(S2): 94-110.

663 Laugen, A.T., Engelhard, G.H., Whitlock, R., Arlinghaus, R., Dankel, D.J., Dunlop, E.S., 664 Eikeset, A.M., Enberg, K., Jørgensen, C., Matsumura, S., Nusslé, S., Urbach, D., Baulier, L., 665 Boukal, D.S., Ernande, B., Johnston, F.D., Mollet, F., Pardoe, H., Therkildsen, N.O., Uusi666 Heikkilä, S., Vainikka, A., Heino, M., Rijnsdorp, A.D., and Dieckmann, U. 2014. 667 Evolutionary impact assessment: accounting for evolutionary consequences of fishing in an 668 ecosystem approach to fisheries management. Fish. Fish. 15(1): 65-96.

669 Lecchini, D., Shima, J., Banaigs, B., and Galzin, R. 2005. Larval sensory abilities and 670 mechanisms of habitat selection of a coral reef fish during settlement. Oecologia 143(2): 326671334.

672 Lester, S.E., Halpern, B.S., Grorud-Colvert, K., Lubchenco, J., Ruttenberg, B.I., Gaines, 673 S.D., Airamé, S., and Warner, R.R. 2009. Biological effects within no-take marine reserves: a 674 global synthesis. Mar. Ecol. Prog. Ser. 384: 33-46. 
675 Liu, C., Berry, P.M., Dawson, T.P., and Pearson, R.G. 2005. Selecting thresholds of 676 occurrence in the prediction of species distributions. Ecography 28: 385-393.

677 McCook, L.J., Ayling, T., Cappo, M., Choat, J.H., Evans, R.D., De Freitas, D.M., Heupel, 678 M., Hughes, T.P., Jones, G.P., Mapstone, B., Marsh, H., Mills, M., Molloy, F.J., Pitcher, 679 C.R., Pressey, R.L., Russ, G.R., Sutton, S., Sweatman, H., Tobin, R., Wachenfeld, D.R., and 680 Williamson, D.H. 2010. Adaptive management of the Great Barrier Reef: A globally 681 significant demonstration of the benefits of networks of marine reserves. P. Natl. Acad. Sci. 682 USA 107(43): 18286-18293.

683 Moffitt, E.A., White, J.W., and Botsford, L.W. 2011. The utility and limitations of size and 684 spacing guidelines for designing marine protected area (MPA) networks. Biol. Conserv. 685 144(1): 306-318. doi: 10.1016/j.biocon.2010.09.008.

686 Morato, T., Afonso, P., Lourinho, P., Barreiros, J.P., Santos, R.S., and Nash, R.D.M. 2001. 687 Length-weight relationships for 21 coastal fish species of the Azores, north-eastern Atlantic. 688 Fish. Res. 5: 297-302.

689 Morato, T., Afonso, P., Lourinho, P., Nash, R.D.M, and Santos, R.S. 2003. Reproductive 690 biology and recruitment of the white sea bream in the Azores. J. Fish. Biol. 63: 59-72.

691 Owen, A.B. 1995. Nonparametric Confidence Bands for a Distribution Function. J. Am. Stat. 692 Assoc. 90(430): 516-521.

693 Pelc, R.A., Warner, R.R., Gaines, S.D., and Paris, C.B. 2010. Detecting larval export from 694 marine reserves. P. Natl. Acad. Sci. USA 107(43): 18266-18271.

695 Pineda, J., Hare, J.A., and Sponaugle, S. 2007. Larval transport and dispersal in the coastal 696 ocean and consequences for population connectivity. Oceanography 20(3): 22-39.

697 Pittman, S.J., Costa, B.M., and Battista, T.A. 2009. Using lidar bathymetry and boosted 698 regression trees to predict the diversity and abundance of fish and corals. J. Coast. Res. Spec. 699 Issue 53: 27-38. 
700 Planes, S., Jones, G.P., and Thorrold, S.R. 2009. Larval dispersal connects fish populations in

701 a network of marine protected areas. P. Natl. Acad. Sci. USA 106(14): 5693-5697.

702 R Development Core Team. 2011. R: A language and environment for statistical computing.

703 R Foundation for Statistical Computing, Vienna, Austria. R version 2.14.1.

704 Rigby, R.A., and Stasinopoulos, D.M. 2005. Generalized additive models for location, scale 705 and shape. Appl. Stat.-J. Roy. St. C 54(3): 507-554.

706 Russ, G.R. 2002. Yet another review of marine reserves as reef fishery management tools. In

707 Coral reef fishes: dynamics and diversity in a complex ecosystem. Edited by P.F. Sale. 708 Academic Press, San Diego, CA, USA, pp. 421-443.

709 Sale, P.F., Cowen, R.K., Danilowicz, B.S., Jones, G.P., Kritzer, J.P., Lindeman, K.C., Planes,

710 S., Polunin, N.V.C., Russ, G.R., Sadovy, Y.J., and Steneck, R.S. 2005. Critical science gaps

711 impede use of no-take fishery reserves. Trends Ecol. Evol. 20(2): 74-80.

712 Santos, R.S., Hawkins, S., Monteiro, L.R., Alves, M., and Isidro, E.J. 1995. Marine research, 713 resources and conservation in the Azores. Aquat. Conserv. 5: 311-354.

714 Schmiing, M., Afonso, P., Tempera, F., and Santos, R.S. 2013. Predictive habitat modelling 715 of reef fishes with contrasting life histories. Mar. Ecol. Prog. Ser. 474: 201-216.

716 Schmiing, M., Afonso, P., and Santos, R.S. 2014a. Coastal marine protected areas in the

717 Azores: opportunities, benefits and limitations. In The sea of the Azores: scientific forum for

718 decision support. Edited by G. Carreira, F. Cardigos, and F.M. Porteiro. Arquipel. Life Mar.

719 Sci. Supplement 8, pp. 71-74.

720 Schmiing, M., Diogo, H., Santos, R.S., and Afonso, P. 2014b. Assessing hotspots within 721 hotspots to conserve biodiversity and support fisheries management. Mar. Ecol. Prog. Ser. 722 513: 187-199. 
723 Schmiing, M., Diogo, H., Santos, R.S., and Afonso, P. 2015. Marine conservation of

724 multispecies and multi-use areas with various conservation objectives and targets. ICES J.

725 Mar. Sci. 72(3): 851-862. doi:10.1093/icesjms/fsu180.

726 Soeparno, Nakamura, Y., and Yamaoka, K. 2013. Habitat choice and recruitment of tropical

727 fishes on temperate coasts of Japan. Environ. Biol. Fish. 96(9): 1101-1109.

728 doi:10.1007/s10641-012-0106-2.

729 Stasinopoulos, D.M., and Rigby, R.A. 2007. Generalized Additive Models for Location Scale 730 and Shape (GAMLSS) in R. J. Stat. Softw. 23(7): 1-46.

731 Sundblad, G., Bergström, U., and Sandström, A. 2011. Ecological coherence of marine 732 protected area networks: a spatial assessment using species distribution models. J. Appl. Ecol. 733 48: 112-120.

734 Tempera, F. 2008. Benthic habitats of the extended Faial Island shelf and their relationship to 735 geologic, oceanographic and infralittoral biologic features. Ph.D. thesis, University of St. 736 Andrews. http://research-repository.st-andrews.ac.uk/handle/10023/726.

737 Tempera, F., MacKenzie, M., Bashmachnikov, I., Puotinen, M.L., Santos, R.S., and Bates, R. 738 2012. Predictive modeling of dominant macroalgae abundance on temperate island shelves 739 (Azores, Northeast Atlantic). In Seafloor geomorphology as benthic habitat: GeoHAB Atlas 740 of Seafloor Geomorphic Features and Benthic Habitat. Edited by P.T. Harris and E. Baker. 741 London, Elsevier, pp. 169-182.

742 Thomas, C.J., Lambrechts, J., Wolanski, E., Traag, V.A., Blondel, V.D., Deleersnijder, E., 743 and Hanert, E. 2014. Numerical modelling and graph theory tools to study ecological 744 connectivity in the Great Barrier Reef. Ecol. Model. 272: 160-174.

745 Treml, E.A., Roberts, J.J., Chao, Y., Halpin, P.N., Possingham, H.P., and Riginos, C. 2012.

746 Reproductive output and duration of the pelagic larval stage determine seascape-wide 747 connectivity of marine populations. Integr. Comp. Biol. 52: 525-537. 
748 Underwood, J.N., Wilson, S.K., Ludgerus, L., and Evans, R.D. 2013. Integrating connectivity

749 science and spatial conservation management of coral reefs in north-west Australia. J. Nat.

750 Conserv. 21: 163-172.

751 Van Buuren, S., and Fredriks, M. 2001. Worm plot: a simple diagnostic device for modelling

752 growth reference curves. Stat. Med. 20: 1259-1277.

753 Villegas-Ríos, D., Alonso-Fernández, A., Domínguez-Petit, R., and Saborido-Rey, F. 2014.

754 Energy allocation and reproductive investment in a temperate protogynous hermaphrodite, 755 the ballan wrasse Labrus bergylta. J. Sea Res. 86: 76-85.

756 White, J.W., and Caselle, J.E. 2008. Scale-dependent changes in the importance of larval 757 supply and habitat to abundance of a reef fish. Ecology 89: 1323-1333.

758 Wood, S.N. 2004. Stable and efficient multiple smoothing parameter estimation for 759 generalized additive models. J. Am. Stat. Assoc. 99: 673-686.

760 Wood, S.N., and Augustin, N.H. 2002. GAMs with integrated model selection using 761 penalized regression splines and applications to environmental modelling. Ecol. Model. 157: $762 \quad 157-177$.

763 World Parks Congress. 2003. Recommendation V.22: Building a global system of marine and 764 coastal protected area networks. Vth IUCN World Parks Congress. IUCN, 8-17 September 765 2003, Durban, South Africa.

766 Zuur, A.F., Ieno, E.N., and Smith, G,M, 2007 Analysing ecological data. Springer, New 767 York.

768 Zuur, A.F., Ieno, E.N., and Elphick, C.S. 2010. A protocol for the data exploration to avoid 769 common statistical problems. Methods Ecol. Evol. 1: 3-14.

770 
772 Table 1: Summary of the (reproductive) ecology of four reef fishes, showing fecundity 773 equations used to estimate the potential fecundity (number of oocytes) of mature females via 774 the mean length (TL, in cm; Morato et al. 2001) of species-specific size classes (M- medium, 775 L - large, XL - very large).

\begin{tabular}{|c|c|c|c|}
\hline Species & $\begin{array}{l}\text { Reproductive } \\
\text { strategy }\end{array}$ & Fecundity & $\mathrm{TL}(\mathrm{cm})$ \\
\hline Diplodus & Digynic & $25398 \mathrm{TL}-484426$ & M: 17; L: 26, XL: 36 \\
\hline sargus & hermaphrodite & $\left(\right.$ Gonçalves and Erzini 2000) ${ }^{a}$ & \\
\hline Serranus & Simultaneous & $63,648.435 * 1.1380^{\mathrm{TL}}$ & M: 25; L: 32.5; XL: 40 \\
\hline atricauda & hermaphrodite & $\left(\right.$ García-Díaz et al. 2006) ${ }^{b}$ & \\
\hline Sparisoma & Gonochoristic, & $9.158 * 10^{-8} * \mathrm{TL}^{5.0954}$ & M: 27.5; L: 37.5; XL: 47 \\
\hline cretense & prematurational & $\left(\right.$ Gonzáles et al. 1993) ${ }^{c}$ & \\
\hline & sex-change & & \\
\hline Labrus & Protogynous & $1.4377 * \mathrm{TL}^{3.7276}$ (Villegas- & M: 24; L: 32.5; XL: 42.5 \\
\hline bergylta & hermaphrodite & Ríos et al. 2014) & \\
\hline
\end{tabular}

$776{ }^{a}$ Equation for Diplodus vulgaris. ${ }^{b}$ Published equation was corrected (pers. com. V. Tuset).

$777{ }^{c} \mathrm{TL}$ in equation in $\mathrm{mm}$.

778

779

780

781

782 
783 Table 2: Modeled occurrences of mature individuals of three reef fishes, including the 784 percentage of rocky reef habitat down to $40 \mathrm{~m}$ depth $(\%$ Reef) with predicted presence $(\geq$

785 threshold) and the representativeness of these reef areas inside the existing marine protected 786 area

787 network (\% MPA).

\begin{tabular}{lccc}
\hline Species & Threshold $^{a}$ & \% Reef & \% MPA \\
\hline Labrus bergylta & 0.34 & 59.1 & 60.3 \\
Sparisoma cretense & 0.55 & 56.7 & 66.8 \\
Symphodus caeruleus & 0.34 & 57.1 & 66.2
\end{tabular}

$788{ }^{a}$ The 'equal sensitivity and specificity' approach was used for identifying species-specific

789 thresholds of presence. Note: Occurrences were modeled with binomial generalized additive 790 models.

791

792 


\section{$793 \quad$ Figure captions}

794 Fig. 1: Map of the study area. 462 underwater visual censuses (dots; dots of neighboring 795 transects overlap in the figure) were conducted down to the $40 \mathrm{~m}$ isobath in the Azores archipelago. Rocky substrate (grey), 10m isobaths (grey lines) down to 40m, and the outline of the existing marine protected areas are shown (black squares; note that not all areas are visible at this spatial scale).

Fig. 2: Maps of the predictive relative spawning biomass (5m grid) of four reef fishes down to $40 \mathrm{~m}$ in Faial and West Pico Island, Azores archipelago. Biomass predictions are represented i) as relative potential spawning biomass (ratio of a given predicted value to the maximum predicted biomass on a scale from $0-1$, see common color code below maps; Abudefduf luridus, Coris julis, Sarpa salpa) or ii) as probability of occurrence of mature individuals (Symphodus caeruleus; note the individual scale bar). The outline of existing marine protected areas (black squares) and rocky substrate down to $40 \mathrm{~m}$ is shown (black line). (Fish illustrations: L. Gallagher/fishpics/ImagDOP).

Fig. 3: Maps of the predictive spawning biomass (left column) and potential fecundity (right column) (5m grid) of four reef fishes down to $40 \mathrm{~m}$ in Faial and West Pico Islands, Azores

811 archipelago. Predictions are represented i) as relative potential spawning biomass (ratio of a

812 given predicted value to the maximum predicted biomass on a scale from $0-1$, see common

813 color code below maps; Diplodus sargus, Serranus atricauda), ii) as probability of 814 occurrence of mature individuals (Labrus bergylta, Sparisoma cretense; note the individual 815 scale bars in the respective map), or iii) as relative potential fecundity (ratio of a given 816 predicted value the predicted maximum fecundity on a scale from $0-1$, see common color 817 code below maps; all species). Other details as in Fig. 2. 
819 Fig. 4: Summary of the percentage of available rocky reef habitat down to 40m depth, 820 suitable for different target levels of the reproductive potential. A) Predictive relative 821 spawning biomass ( $>1 \%,>10 \%,>25 \%,>50 \%$ of the maximum), and $\mathrm{B}$ ) predictive relative 822 potential fecundity $(>1 \%,>10 \%,>25 \%,>50 \%$ of the maximum). Potential multi-species

823 reproductive habitats combine either commercial $\left(^{*}\right)$ or all species $(+)$, including results of 824 binomial models (see text for detail). Numbers indicate the representativeness (\% included) 825 of the identified areas inside the existing MPA network.

826

827 Fig. 5: Predicted reproductive habitats (RHs) of commercial species (Diplodus sargus, 828 Labrus bergylta, Sparisoma cretense, Serranus atricauda). RHs consider a minimum of 10\% 829 relative spawning biomass $\left(\mathrm{Ws}_{\mathrm{com}}\right)$ or potential fecundity $\left(\mathrm{Fp}_{\mathrm{com}}\right)$. Areas with overlapping $830 \mathrm{Fp}_{\text {com }}$ and $\mathrm{Ws}_{\text {com }}$ are dark shaded. The threshold of occurrence was used as alternative 831 criterion for predictions of the spawning biomass of L. bergylta and S. cretense (see text for 832 more details). The outline of rocky bottom down to $40 \mathrm{~m}$ (black line) and the marine protected 833 area network (black squares) of Faial and Pico Islands in the Azores archipelago are shown. 


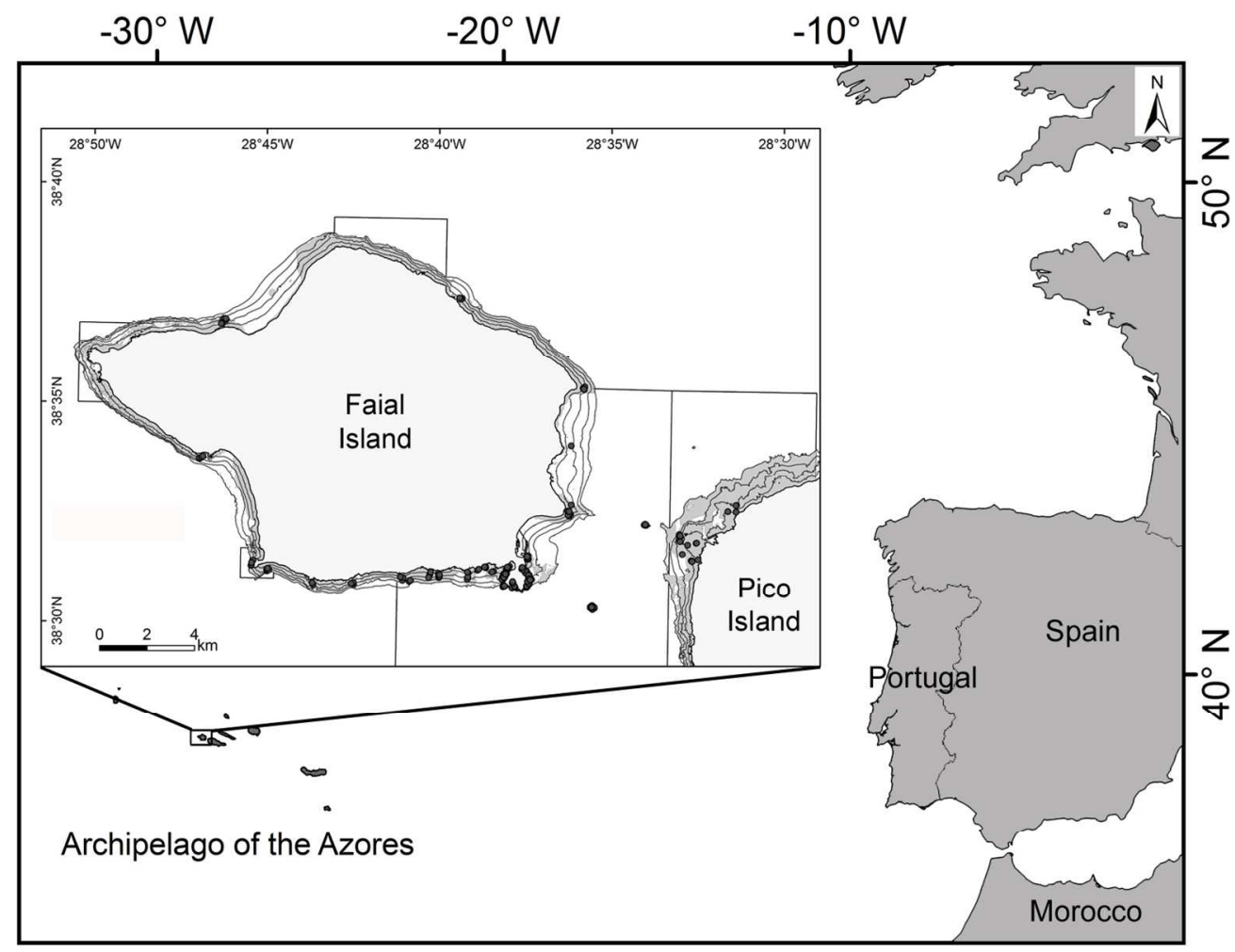

Fig. 1: Map of the study area. 462 underwater visual censuses (dots; dots of neighboring transects overlap in the figure) were conducted down to the $40 \mathrm{~m}$ isobath in the Azores archipelago. Rocky substrate (grey), $10 \mathrm{~m}$ isobaths (grey lines) down to $40 \mathrm{~m}$, and the outline of the existing marine protected areas are shown (black squares; note that not all areas are visible at this spatial scale).

Fig. 1

$140 \times 108 \mathrm{~mm}(300 \times 300 \mathrm{DPI})$ 

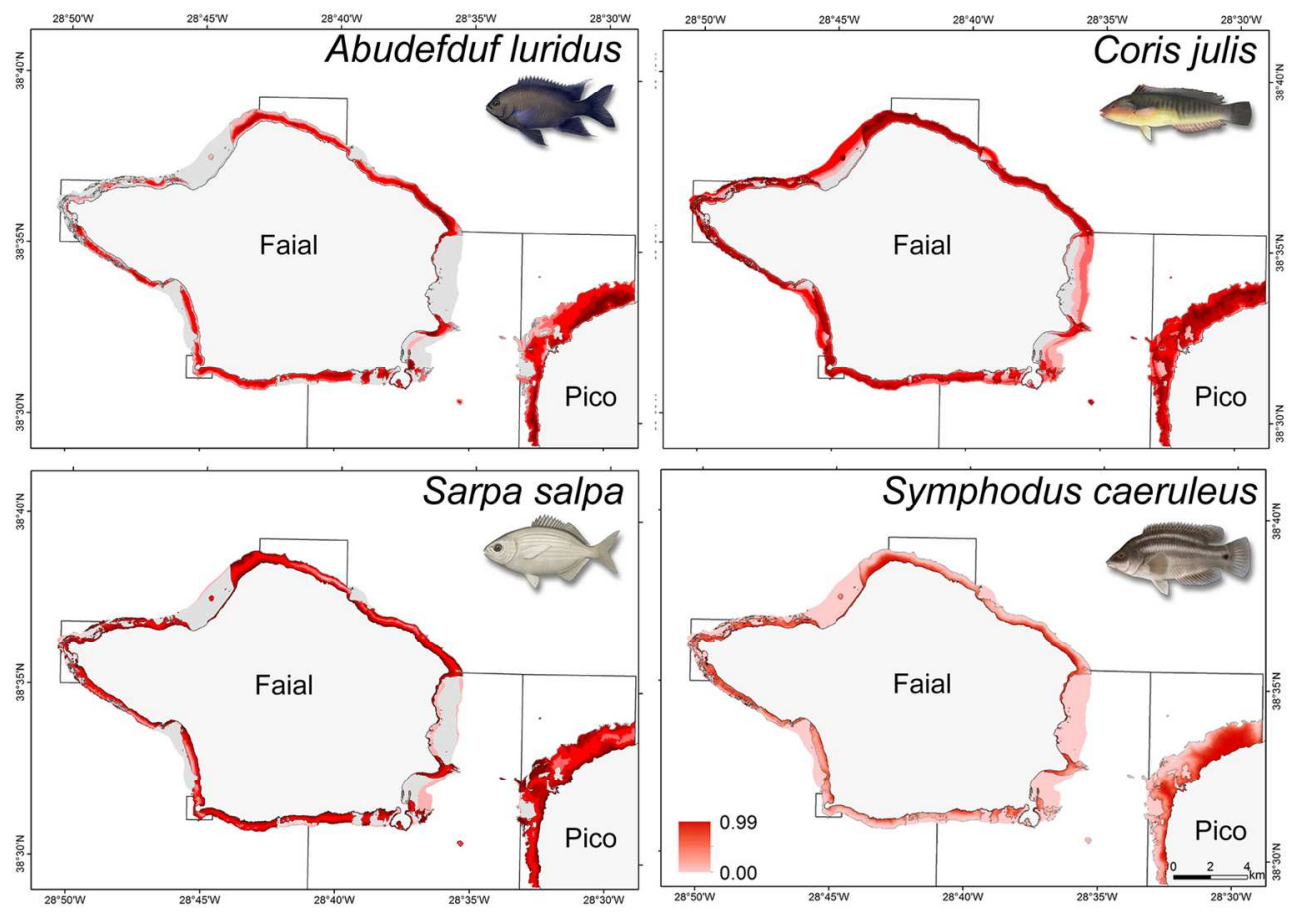

$\square<0.01 \square>0.01-0.05 \square>0.05-0.10 \square>0.10-0.25 \square>0.25-0.50 \square 0.50-1.00$

Fig. 2: Maps of the predictive relative spawning biomass ( $5 \mathrm{~m}$ grid) of four reef fishes down to $40 \mathrm{~m}$ in Faial and West Pico Island, Azores archipelago. Biomass predictions are represented i) as relative potential spawning biomass (ratio of a given predicted value to the maximum predicted biomass on a scale from $0-1$, see common color code below maps; Abudefduf luridus, Coris julis, Sarpa salpa) or ii) as probability of occurrence of mature individuals (Symphodus caeruleus; note the individual scale bar). The outline of existing marine protected areas (black squares) and rocky substrate down to $40 \mathrm{~m}$ is shown (black line). (Fish illustrations: L. Gallagher/fishpics/ImagDOP).

Fig. 2

$142 \times 119 \mathrm{~mm}(300 \times 300 \mathrm{DPI})$ 


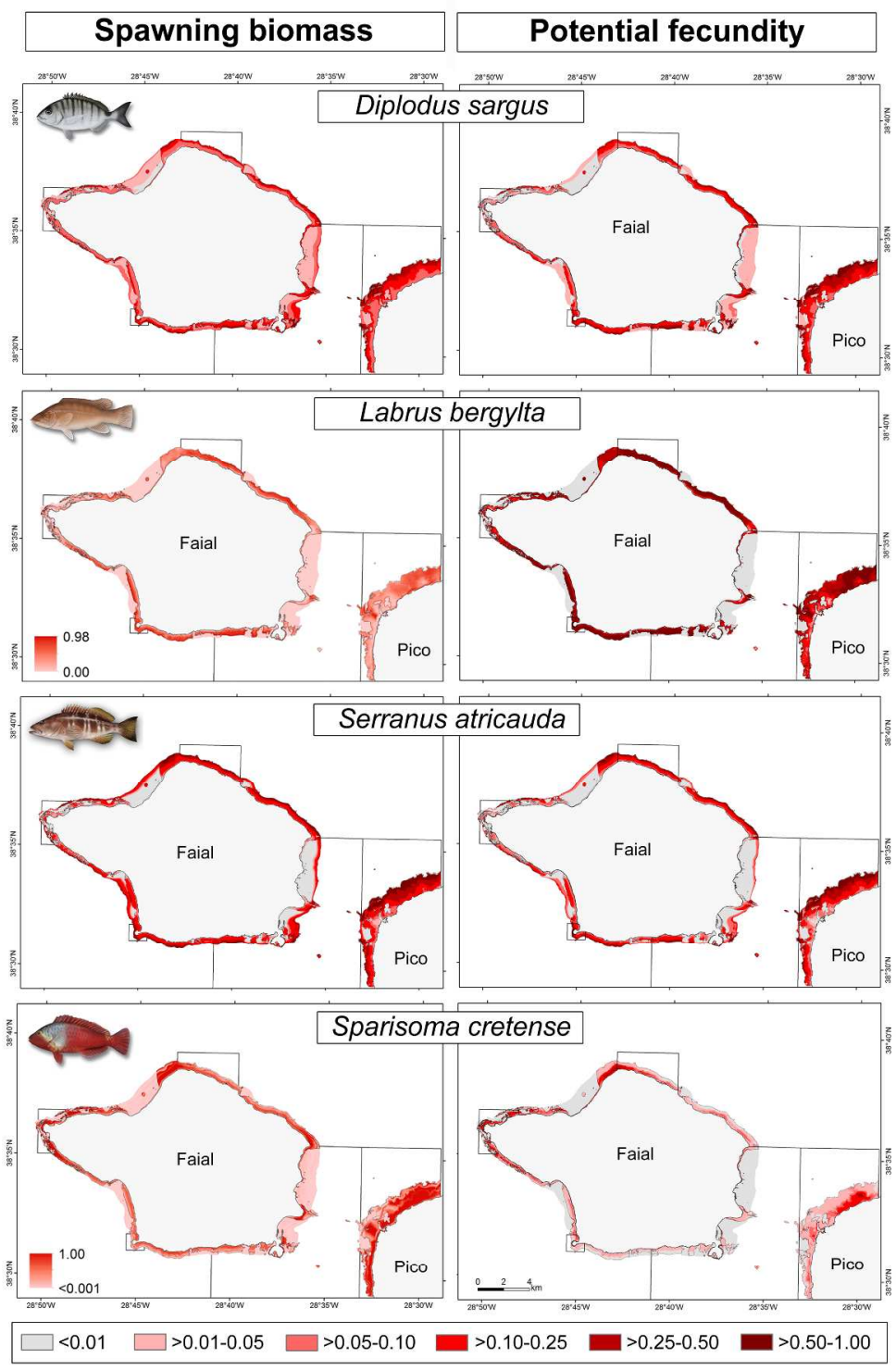

Fig. 3: Maps of the predictive spawning biomass (left column) and potential fecundity (right column) (5m grid) of four reef fishes down to $40 \mathrm{~m}$ in Faial and West Pico Islands, Azores archipelago. Predictions are represented i) as relative potential spawning biomass (ratio of a given predicted value to the maximum predicted biomass on a scale from 0-1, see common color code below maps; Diplodus sargus, Serranus atricauda), ii) as probability of occurrence of mature individuals (Labrus bergylta, Sparisoma cretense; note the individual scale bars in the respective map), or iii) as relative potential fecundity (ratio of a given predicted value the predicted maximum fecundity on a scale from $0-1$, see common color code below maps; all species). Other details as in Fig. 2.

Fig. 3

$264 \times 413 \mathrm{~mm}(300 \times 300 \mathrm{DPI})$ 

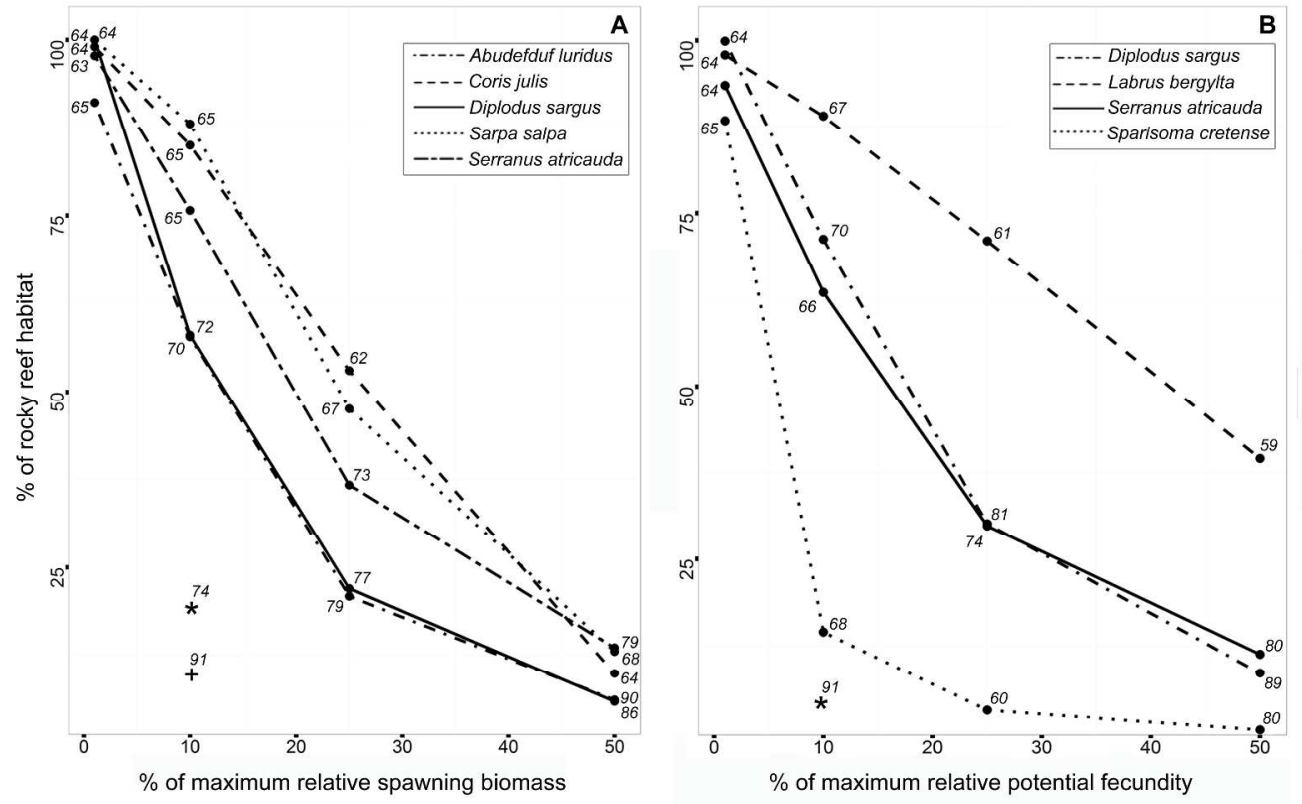

$400 \times 249 \mathrm{~mm}(200 \times 200 \mathrm{DPI})$ 


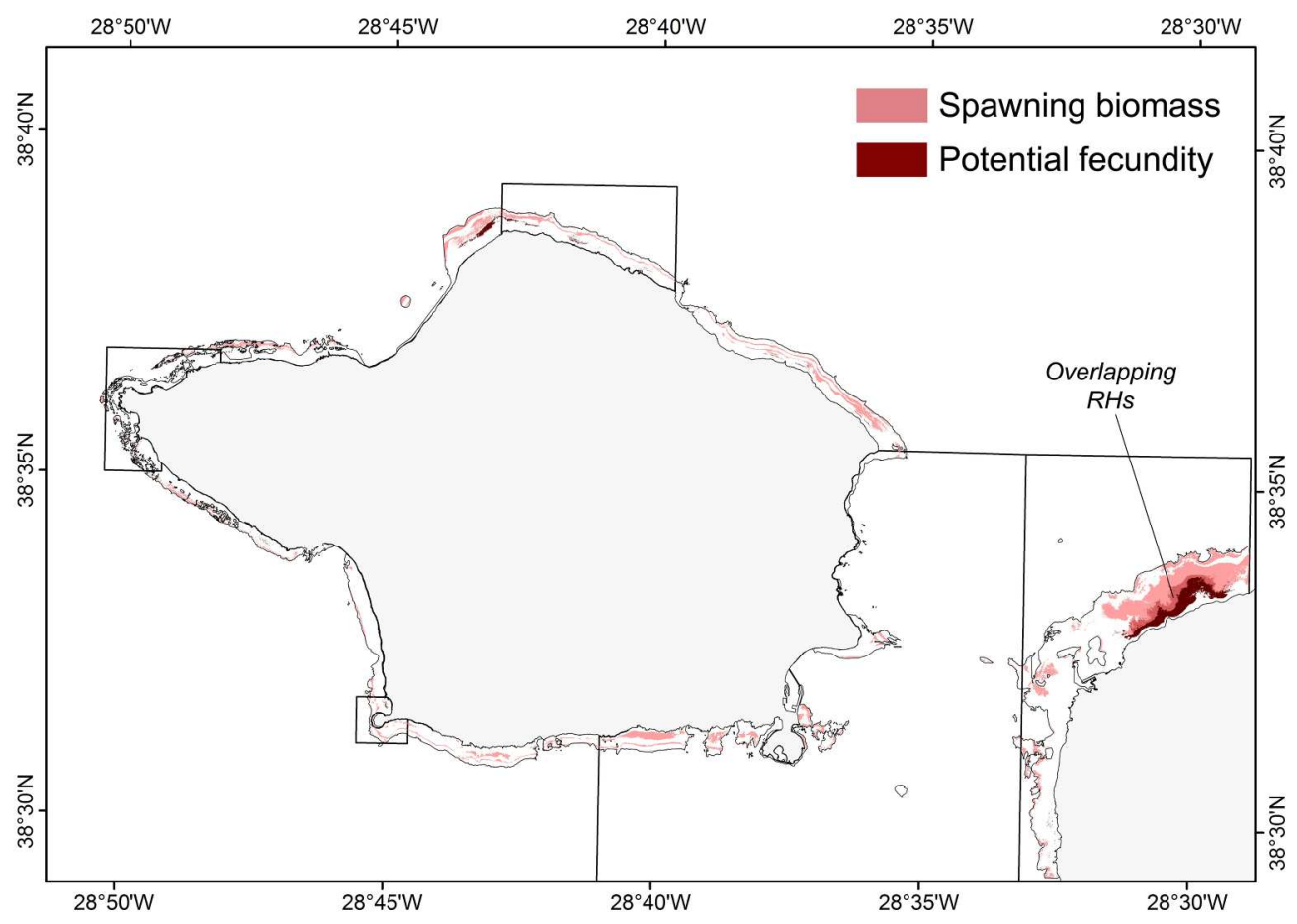

Fig. 5: Predicted reproductive habitats (RHs) of commercial species (Diplodus sargus, Labrus bergylta, Sparisoma cretense, Serranus atricauda). RHs consider a minimum of $10 \%$ relative spawning biomass (Wscom) or potential fecundity (Fpcom). Areas with overlapping Fpcom and Wscom are dark shaded. The threshold of occurrence was used as alternative criterion for predictions of the spawning biomass of L. bergylta and S. cretense (see text for more details). The outline of rocky bottom down to 40m (black line) and the marine protected area network (black squares) of Faial and Pico Islands in the Azores archipelago are shown.

Fig. 5

$209 \times 148 \mathrm{~mm}(300 \times 300$ DPI $)$ 


\section{Supplementary material}

2 Table S1: Summary of final generalised additive models for location, scale and shape

3 (GAMLSS) for continuous response variables and generalised additive models (GAM) for

4 binomial response variables. Environmental variables include depth, slope, distance to

5 sediment (DistSed, log transformed), exposure to current (current, square root transformed)

6 and exposure to swell. GAMLSS include separate formulas for the mu and nu parameters

7 and, if applicable, penalised b-splines ( $\mathrm{pb}$ ) as smooth terms. GAMs used thin plate regression

8 splines (s) and the upper limit of the degrees of freedom was fixed manually $(k=n)$, if

9 applicable. The model fitting data set comprised 354 underwater visual fish censuses.

\begin{tabular}{|c|c|c|}
\hline Response & Spawning biomass & Potential fecundity \\
\hline $\begin{array}{l}\text { Diplodus } \\
\text { sargus }\end{array}$ & $\begin{array}{l}M u: \sim \operatorname{pb}(\text { Depth })^{* * *}+\text { Swell}^{*} \\
N u: \sim \text { pb(DistSed) })^{* * *}\end{array}$ & $\begin{array}{l}M u: \sim \text { Depth*** + DistSed } * * *+\text { Swell }^{* *} ; \\
N u: \sim \operatorname{pb}(\text { DistSed })^{* * *}\end{array}$ \\
\hline $\begin{array}{l}\text { Labrus } \\
\text { bergylta }\end{array}$ & $\begin{array}{l}\text { Binomial model: } \sim \mathrm{s}(\text { Depth }) * * *+\mathrm{s}(\text { Slope })^{* * *}+ \\
\mathrm{s}(\text { DistSed }) *+\mathrm{s}(\text { Current }, \mathrm{k}=6)^{* * *}\end{array}$ & $\begin{array}{l}M u: 1 ; \\
N u: \sim \text { pb(Depth) })^{* * *}+\mathrm{pb}(\text { Slope })^{* * *}+ \\
\mathrm{pb}(\text { DistSed })^{* * *}+\mathrm{pb}(\text { Current })^{* * *}\end{array}$ \\
\hline $\begin{array}{l}\text { Serranus } \\
\text { atricauda }\end{array}$ & $\begin{array}{l}M u: \sim \operatorname{pb}(\text { Depth })^{* * *}+\text { DistSed }^{* * *} \\
N u: \sim \operatorname{pb}(\text { Depth })^{* * *}+\mathrm{pb}(\text { DistSed })^{* * *}+ \\
\mathrm{pb}(\text { Current })^{* * *}\end{array}$ & $\begin{array}{l}M u: \sim \mathrm{pb}(\text { Depth })^{* * *}+\mathrm{pb}(\text { DistSed })^{* * *} \\
N u: \sim \mathrm{pb}(\text { Depth })^{* * *+} \mathrm{pb}(\text { DistSed })^{* * *+} \\
\text { Current }^{2 * *}\end{array}$ \\
\hline $\begin{array}{l}\text { Sparisome } \\
\text { cretense }\end{array}$ & $\begin{array}{l}\text { Binomial model: } \sim \mathrm{s}(\text { Depth }) * * *+\mathrm{s}(\text { DistSed }) * * * \\
+\mathrm{s}(\text { Current }, \mathrm{k}=6)^{* * *}\end{array}$ & $\begin{array}{l}M u: \sim \operatorname{pb}(\text { Slope })^{* * *}+\mathrm{pb}(\text { DistSed })^{* * *+} \\
\mathrm{pb}(\text { Swell }) * \\
N u: \sim \mathrm{pb}(\text { Depth })^{* * *}+\mathrm{pb}(\text { DistSed })^{* * *}+ \\
\text { Current } * *+\text { Swell }{ }^{* * *}\end{array}$ \\
\hline $\begin{array}{l}\text { Abudefduf } \\
\text { luridus }\end{array}$ & $\begin{array}{l}M u: \sim \operatorname{pb}(\text { Depth })^{*}+\text { DistSed* }+ \text { pb(Current) } \\
\left.N u: \sim \text { pb(Depth) })^{* *}+\text { pb(DistSed }\right)^{* *}+\text { Swell }^{* * *}\end{array}$ & NA \\
\hline Coris julis & $\begin{array}{l}\left.M u: \sim \operatorname{pb}(\text { Depth })^{* * *}+\text { Slope*** }+ \text { pb(Swell) }\right)^{* * *} \\
N u: \sim \text { pb(Depth) }\end{array}$ & NA \\
\hline Sarpa salpa & $\begin{array}{l}M u: \sim \mathrm{pb}(\text { Depth })^{\mathrm{ns}} ; \\
N u: \sim \mathrm{pb}(\text { Depth })^{* *}+\mathrm{pb}(\text { DistSed })^{* * *}+\end{array}$ & NA \\
\hline
\end{tabular}




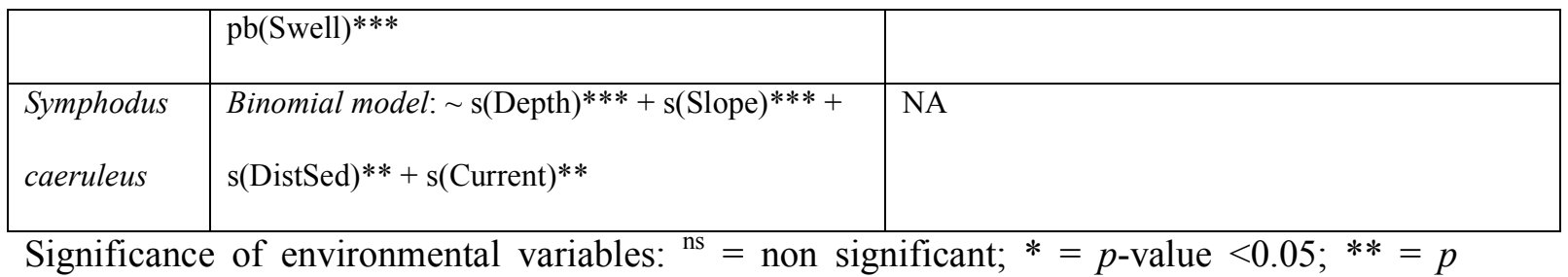

10 Significance of environmental variables: ${ }^{\text {ns }}=$ non significant; $*=p$-value $<0.05 ; * *=p$

$11<0.01 ; * * *=p<0.001 . \mathrm{NA}=$ not applicable because no model was produced.

14 Table S2: Validation of model for the predictive spawning biomass and potential fecundity 15 of reef fishes in the Azores. The Spearman's rank correlation coefficient, rho, between 16 predicted and observed values in the model fitting (Rho-fit, $\mathrm{n}=354$ ) and validation data set 17 (Rho-validate, $\mathrm{n}=108$ ) is given. All $p$-values are $<0.001$. The validation of three binomial 18 models also includes the area under the curve (AUC). NA = not applicable.

\begin{tabular}{lccc|cc}
\hline Species & \multicolumn{3}{c|}{ Spawning biomass } & \multicolumn{2}{c}{ Potential fecundity } \\
& Rho-fit & Rho-validate & AUC & Rho-fit & Rho-validate \\
\hline Diplodus sargus & 0.58 & 0.55 & NA & 0.57 & 0.62 \\
Labrus bergylta & 0.55 & 0.58 & 0.85 & 0.57 & 0.57 \\
Serranus atricauda & 0.70 & 0.75 & NA & 0.72 & 0.70 \\
Sparisome cretense & 0.62 & 0.47 & 0.86 & 0.42 & 0.43 \\
Abudefduf luridus & 0.74 & 0.68 & NA & NA & NA \\
Coris julis & 0.69 & 0.62 & NA & NA & NA \\
Sarpa salpa & 0.54 & 0.50 & NA & NA & NA \\
Symphodus caeruleus & 0.52 & 0.34 & 0.84 & NA & NA \\
\hline
\end{tabular}

19 


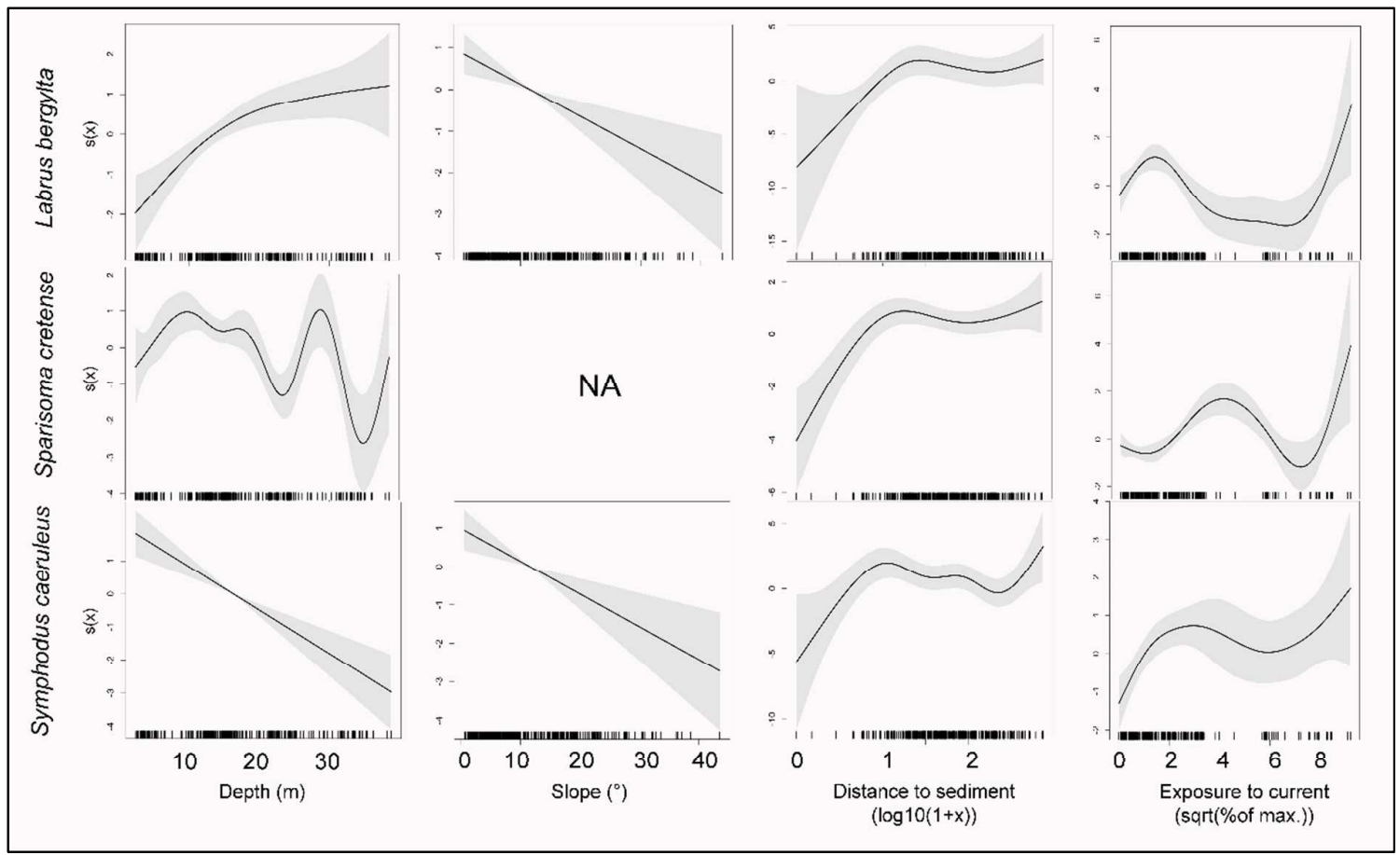

21 Fig. S1: Smoother estimates (solid line, $\mathrm{s}(x)$ ) for the environmental variables depth, slope,

22 distance to sediment, and exposure to current obtained by generalised additive models

23 (GAMs) for the occurrence of mature individuals of three reef fishes. Grey shaded areas

24 indicate the approximate $95 \%$ confidence interval. Tick marks on the $\mathrm{x}$-axis are sampled 25 datapoints. $\mathrm{NA}=$ not applicable. 


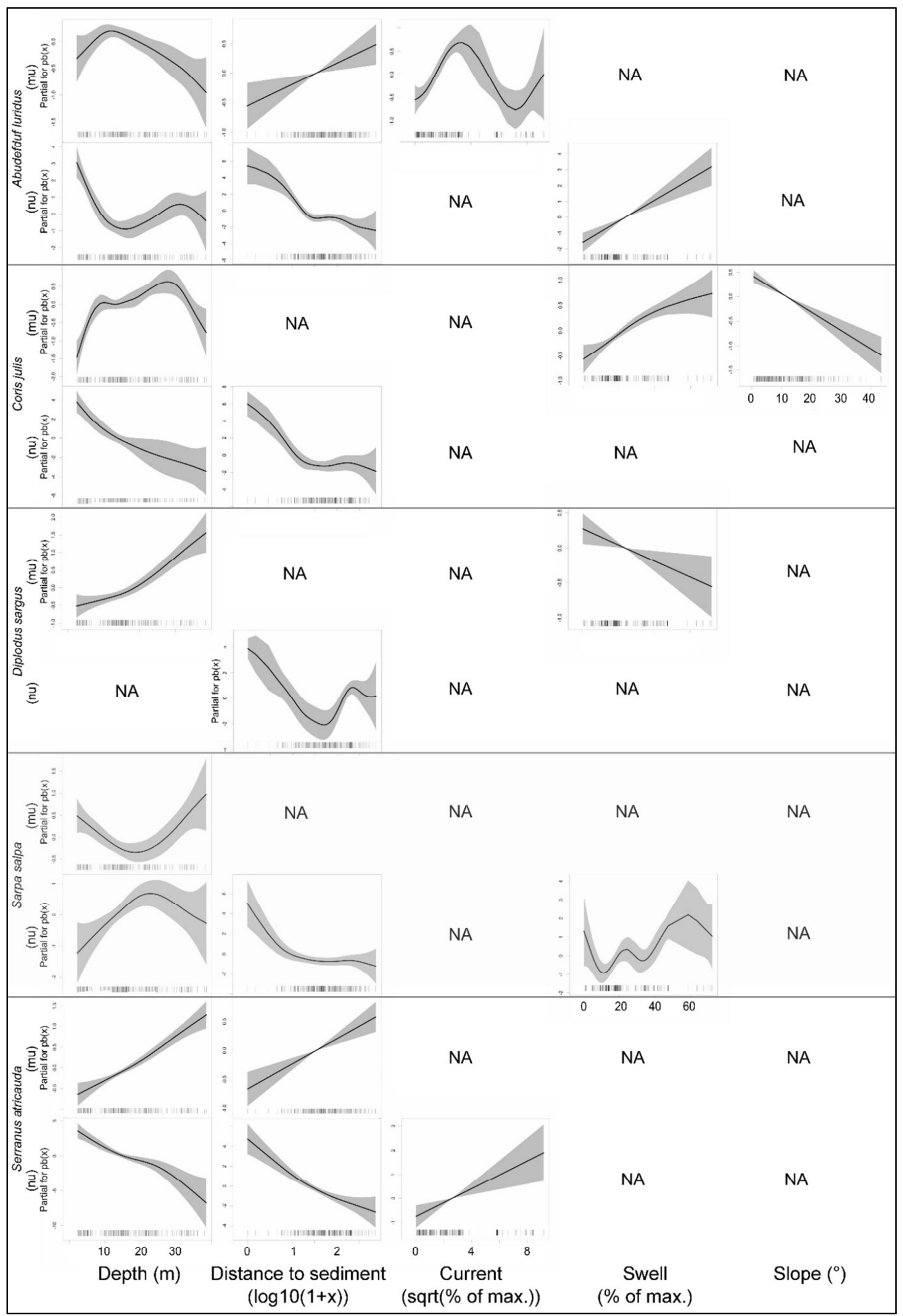

Fig. S2: Model results for the spawning biomass of mature individuals of four commercially

29 valuable reef fishes. Smoother estimates (solid line, $\mathrm{pb}(x)$ ) for up to five environmental 
30 variables, as obtained for the mu (mean of the response variable) and nu (probabilities at

31 zero) parameters of generalised additive models for location, scale and shape (GAMLSS) are

32 given. Grey shaded areas indicate the approximate $95 \%$ confidence interval. NA $=$ not 33 applicable. Tick marks above the $\mathrm{x}$-axis are sampled datapoints. 


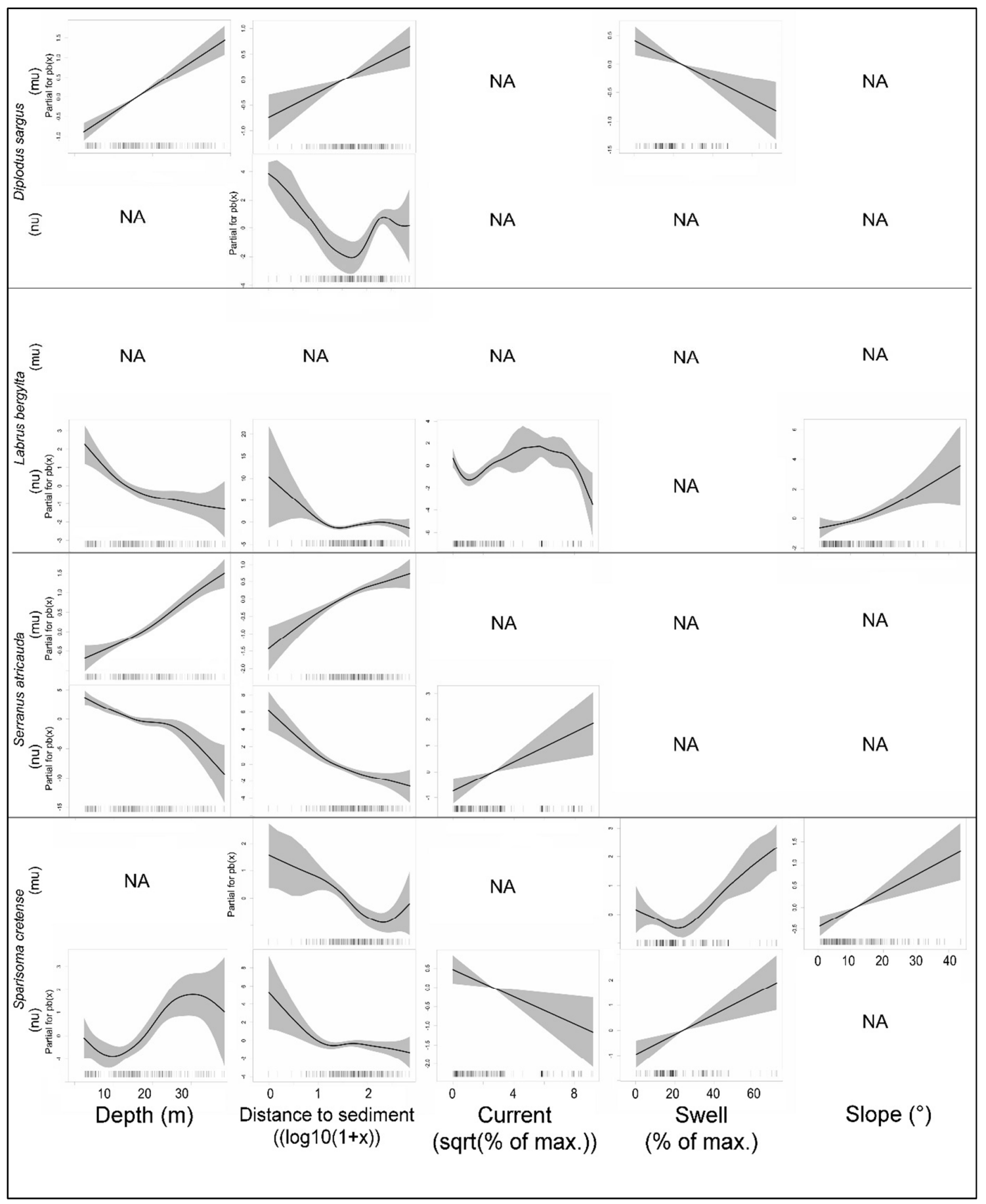

36 Fig. S3: Model results for the potential fecundity of four commercially valuable reef fishes.

37 Smoother estimates (solid line, $\mathrm{pb}(x)$ ) for up to five environmental variables, as obtained for

38 the mu and nu parameter of generalised additive models for location, scale and shape

39 (GAMLSS) are given. Other details as in Fig. S2. 